\title{
Preliminary Assessment of the Low-Temperature Waste Form Technology Coupled with Technetium Removal
}

\author{
PNNL \\ CF Brown \\ JH Westsik, Jr \\ RJ Seme \\ BM Rapko
}

SRNL

WR Wilmarth

DJ McCabe

CA Nash

AD Cozzi

KMFox

May 2014

Savannah River National Laboratory Savannah River Nuclear Solutions, LLC Aiken, SC 29808
Pacific Northwest National Laboratory P.O. Box 999

Richland, WA 99352

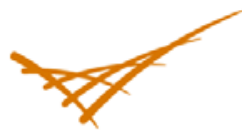

Pacific Northwest

NATIONAL LABORATORY 
SRNL-STI-2013-00002

PNNL-22103

Revision 1

\section{DISCLAIMER}

This document was prepared in conjunction with work accomplished under Contract No. DE-AC09-08SR22470 with the U.S. Department of Energy.

This work was prepared under an agreement with and funded by the U.S. Government. Neither the U.S. Government or its employees, nor any of its contractors, subcontractors or their employees, makes any express or implied: 1. warranty or assumes any legal liability for the accuracy, completeness, or for the use or results of such use of any information, product, or process disclosed; or 2. representation that such use or results of such use would not infringe privately owned rights; or 3. endorsement or recommendation of any specifically identified commercial product, process, or service. Any views and opinions of authors expressed in this work do not necessarily state or reflect those of the United States Government, or its contractors, or subcontractors.

Printed in the United States of America

Prepared for

U.S. Department of Energy 


\section{REVIEWS AND APPROVALS, REVISION 1}

AUTHORS:

C. F. Brown, Pacific Northwest National Laboratory

Date

K. M. Fox, Savannah River National Laboratory $\quad$ Date

APPROVAL:

S. L. Marra, Manager, E\&CPT Research Programs

Date

P. R. Bredt, Manager, Environmental Health and Remediation Sector

Date 


\section{ACKNOWLEDGEMENTS}

The authors appreciate the review comments provided by Paul Bredt and Reid Peterson from PNNL; Sharon Marra, Connie Herman, Roger Seitz, Christine Langton, and Bill King from SRNL, Leo Thompson, Dave Swanberg, and Rebecca Robbins from WRPS, Kent Rosenberger from SRR, and Steve Pfaff from DOE-ORP. Kathy Neiderhiser from PNNL helped with formatting and preparation of the document. 


\section{EXECUTIVE SUMMARY}

The U.S. Department of Energy Office of Environmental Management (EM) is engaging the national laboratories to provide the scientific and technological rigor to support EM program and project planning, technology development and deployment, project execution, and assessment of program outcomes. As an early demonstration of this new responsibility, Pacific Northwest National Laboratory (PNNL) and Savannah River National Laboratory (SRNL) have been chartered to implement a science and technology program addressing low-temperature waste forms for immobilization of DOE aqueous waste streams, including technetium removal as an implementing technology. As a first step, the laboratories examined the technical risks and uncertainties associated with the Cast Stone waste immobilization projects at Hanford. Science and technology needs were identified for work associated with 1) conducting performance assessments and risk assessments of waste form and disposal system performance, and 2) technetium chemistry in tank wastes and separations of technetium from waste processing streams. Technical approaches to address the science and technology needs were identified and an initial sequencing priority was suggested. The following table summarizes the most significant science and technology needs and associated approaches to address those needs. These approaches and priorities will be further refined and developed as strong integrated teams of researchers from national laboratories, contractors, industry, and academia are brought together to provide the best science and technology solutions.

Implementation of a science and technology program that addresses these needs by pursuing the identified approaches will have immediate benefits to DOE in reducing risks and uncertainties associated with near-term decisions regarding supplemental immobilization at Hanford. Longer term, the work has the potential for cost savings and for providing a strong technical foundation for future performance assessments at Hanford and across the DOE complex.

\section{Changes Made in Revision 1}

Revision 1 of this document captures new information learned via studies conducted in fiscal year 2013 and ongoing in fiscal year 2014. Specifically, the following areas have been updated with new data or references:

1. Ongoing WRPS projects reflecting the completed Cast Stone screening matrix study and the high sodium Cast Stone formulation study;

2. Method development for determining the hydraulic conductivity of fractured cementitious materials;

3. Recent work on technetium oxidation measurements for diffusivity determinations;

4. Specific results of the high sodium Cast Stone formulation study;

5. Results of a recent study of hydraulic conductivity of simulated saltstone cured at high relative humidity;

6. Additional references identified to estimate expected fracturing in Cast Stone with time;

7. Additional references for the discussion of the potential inadequacy of chromium as an oxidation sensitive surrogate for technetium;

8. A discussion of recently published results related to binders for granulated waste forms based on encapsulated Fluidized Bed Steam Reforming product studies;

9. Results of recent studies of Tc removal from salt waste and off-gas condensate recycle;

10. Results of recent studies on identifying the conditions for non-pertechnetate species; and

11. New data from studies on the effect of elevated temperature on Tc removal operations. 
SRNL-STI-2013-00002

PNNL-22103

Revision 1

Finally, the new information resulting from these studies was used to update the tables summarizing technology needs below and at the end of this document.

\begin{tabular}{|c|c|}
\hline Technology Need & Approach \\
\hline Effective Diffusion Coefficients & $\begin{array}{l}\text { Extend effective diffusivity measurements in support of the LAW } \\
\text { supplemental immobilization testing program and expanded secondary } \\
\text { waste immobilization tests }\end{array}$ \\
\hline Solubility and $\mathrm{K}_{\mathrm{d}}$ & $\begin{array}{l}\text { Perform additional adsorption-desorption tests using Cast Stone } \\
\text { leachates }\end{array}$ \\
\hline $\begin{array}{l}\text { Cast Stone Formulation and } \\
\text { Impact on Properties }\end{array}$ & $\begin{array}{l}\text { Expand existing LAW supplemental immobilization Cast Stone testing } \\
\text { program to include waste chemistries and increased sodium } \\
\text { concentrations relevant to the secondary waste stream }\end{array}$ \\
\hline $\begin{array}{l}\text { Impact of Curing Conditions and } \\
\text { Scale on Cast Stone Properties }\end{array}$ & Study curing impacts with focus on controlling porosity \\
\hline $\begin{array}{l}\text { Expected Fracturing in Cast } \\
\text { Stone with Time }\end{array}$ & $\begin{array}{l}\text { Perform literature reviews looking at effect of carbonation reactions } \\
\text { and effects of sulfate attack and ettringite formation }\end{array}$ \\
\hline $\begin{array}{l}\text { Technetium Speciation and } \\
\text { Impacts of Redox Changes }\end{array}$ & $\begin{array}{l}\text { Characterize technetium speciation in Cast Stone; } \\
\text { Further develop technetium oxidation front measurement; } \\
\text { Study leaching of non-pertechnetate technetium from Cast Stone }\end{array}$ \\
\hline $\begin{array}{l}\text { Cast Stone Long-Term } \\
\text { Weathering }\end{array}$ & $\begin{array}{l}\text { Study porosity changes with weathering } \\
\text { Complete literature review on natural analogs and ancient cements }\end{array}$ \\
\hline $\begin{array}{l}\text { Removal of Tc from Off-Gas } \\
\text { Streams }\end{array}$ & $\begin{array}{l}\text { Perform screening of Secondary Waste disposal options; } \\
\text { Select candidate process; } \\
\text { Perform technology insertion optimization }\end{array}$ \\
\hline $\begin{array}{l}\text { Identification of Tank } \\
\text { Conditions that form Non- } \\
\text { Pertechnetate Species }\end{array}$ & $\begin{array}{l}\text { Determine whether a Tc(IV) pathway to Tc(I) carbonyl compounds is } \\
\text { viable in alkaline solutions; } \\
\text { Determine the rates of oxidation of n-Tc compounds to better predict } \\
\text { potential changes in the fraction of soluble non-pertechnetate } \\
\text { technetium that may occur upon waste transfers/processing }\end{array}$ \\
\hline $\begin{array}{l}\text { Development of an Alternative } \\
\text { Technetium Removal Elutable } \\
\text { Resin }\end{array}$ & $\begin{array}{l}\text { Develop an alternative to SuperLiq } 639 \text { Tc removal resin to at least a } \\
\text { Technology Readiness Level (TRL) of } 4\end{array}$ \\
\hline $\begin{array}{l}\text { Pretreatment of WTP LAW and } \\
\text { the Temperature Effect on Resin } \\
\text { Performance }\end{array}$ & $\begin{array}{l}\text { Develop Tc isotherms, column ion exchange behavior, and resin } \\
\text { stability at elevated temperatures up to } 50{ }^{\circ} \mathrm{C}\end{array}$ \\
\hline $\begin{array}{l}\text { Alternative Waste Forms for Tc } \\
\text { Eluate }\end{array}$ & $\begin{array}{l}\text { Evaluate alternative immobilization processes for Tc, such as co- } \\
\text { precipitated with iron oxides or sorbed to Sn(II) apatite }\end{array}$ \\
\hline
\end{tabular}




\section{TABLE OF CONTENTS}

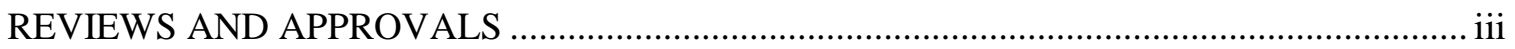

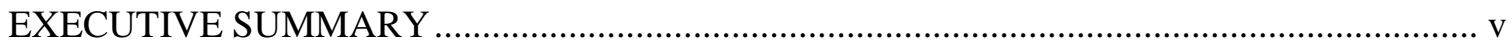

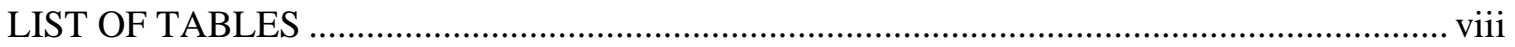

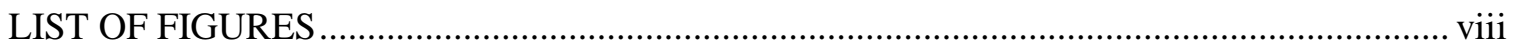

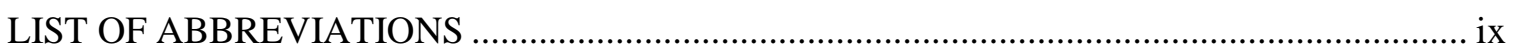

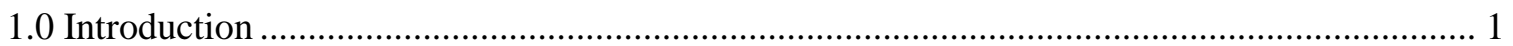

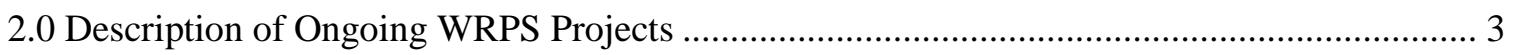

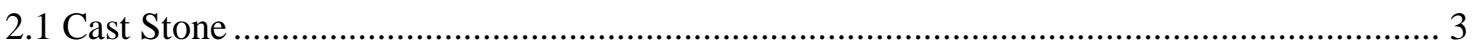

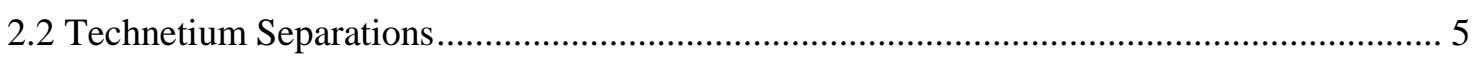

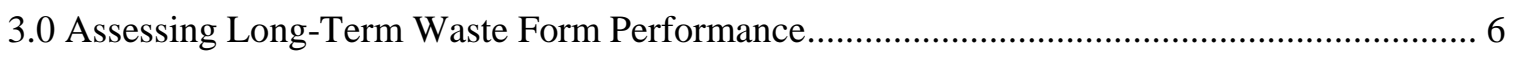

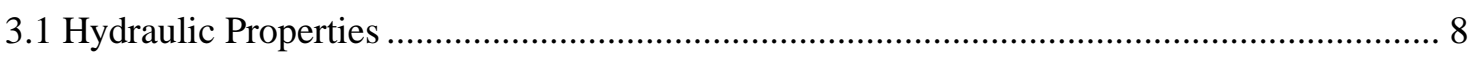

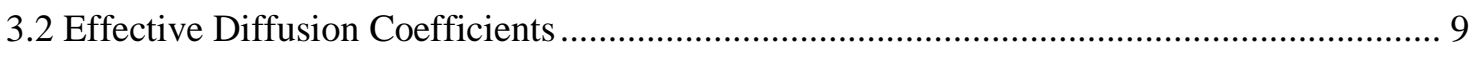

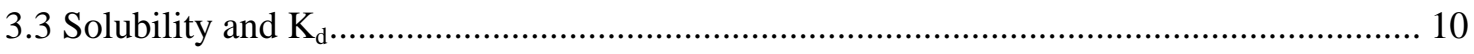

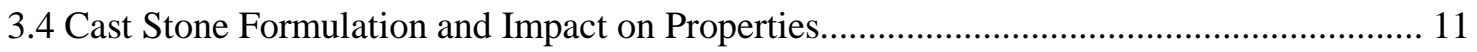

3.5 Impact of Curing Conditions and Scale on Cast Stone Properties...................................... 12

3.6 Expected Fracturing in Cast Stone with Time .................................................................. 13

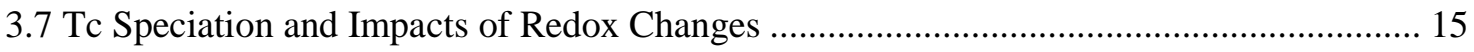

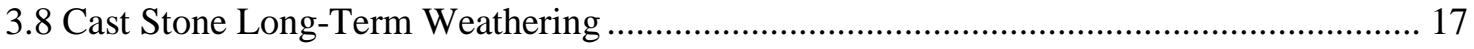

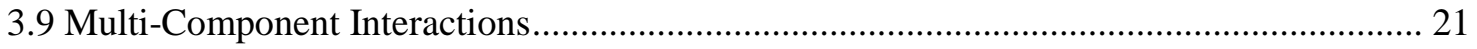

3.10 Cast Stone Contaminant Release Model-Conceptual and Numerical ............................. 22

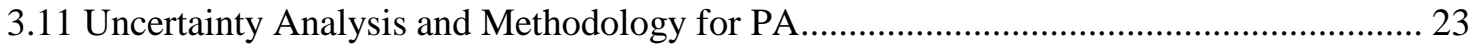

3.12 Transformational Approaches for Waste Solidification ................................................... 24

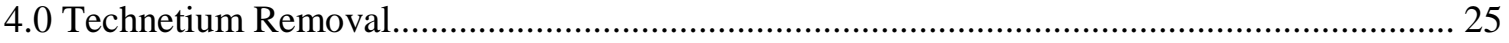

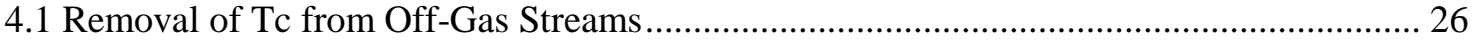

4.2 Identification of Conditions for Non-Pertechnetate Species.............................................. 27

4.3 Development of an Alternative Tc Removal Elutable Resin .............................................. 30

4.4 Pretreatment of WTP LAW and the Temperature Effect on Resin Performance ................ 31

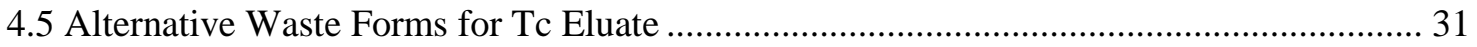

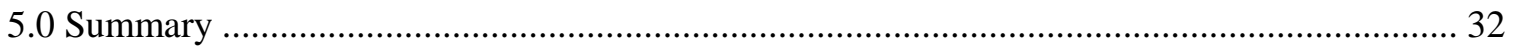

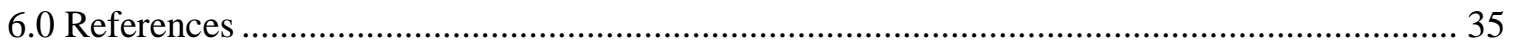




\section{LIST OF TABLES}

Table 5-1. Summary of Technology Needs, Approaches, and Sequencing Priorities

\section{LIST OF FIGURES}

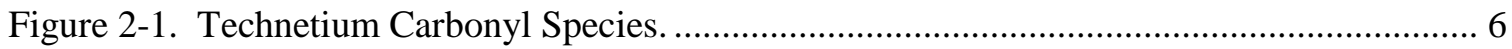

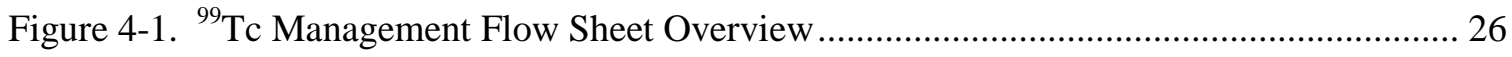




\section{LIST OF ABBREVIATIONS}

\begin{tabular}{|c|c|}
\hline${ }^{99} \mathrm{Tc}$ & technetium-99 \\
\hline AFm & calcium aluminate monosulfate \\
\hline ASCEM & Advanced Simulation Capability for Environmental Management \\
\hline ASTM & American Society for Testing and Materials \\
\hline BET & Brunauer-Emmett-Teller (method) \\
\hline BFS & blast furnace slag \\
\hline $\mathrm{BJH}$ & Barret-Joyner-Halenda (method) \\
\hline C3A & tricalcium aluminate \\
\hline CBP & Cementitious Barriers Partnership \\
\hline $\mathrm{COC}$ & contaminant of concern \\
\hline $\mathrm{Cr}$ & chromium \\
\hline DOE & U.S. Department of Energy \\
\hline ECN & Energy Research Center of the Netherlands \\
\hline EDTA & ethylenediaminetetraacetic acid (a chelating agent) \\
\hline Ecology & Washington State Department of Ecology \\
\hline EM & DOE Office of Environmental Management \\
\hline EPA & U.S. Environmental Protection Agency \\
\hline ETF & Effluent Treatment Facility \\
\hline EXAFS & extended x-ray absorption fine structure \\
\hline FBSR & fluidized bed steam reforming \\
\hline FY & fiscal year \\
\hline HLW & high-level waste \\
\hline I & iodine \\
\hline IAEA & International Atomic Energy Agency \\
\hline IDF & Integrated Disposal Facility \\
\hline ILAW & immobilized low-activity waste \\
\hline $\mathrm{K}_{\mathrm{d}}$ & distribution coefficient (quantifies sorption of a solute to an adsorbent) \\
\hline LAW & low-activity waste \\
\hline LLW & low-level waste \\
\hline NAS & National Academy of Sciences \\
\hline $\mathrm{NE}$ & DOE Office of Nuclear Energy \\
\hline
\end{tabular}




$\begin{array}{ll}\text { NIST } & \text { National Institute of Standards and Technology } \\ \text { NMR } & \text { nuclear magnetic resonance } \\ \text { NRC } & \text { U.S. Nuclear Regulatory Commission } \\ \text { NTA } & \text { nitrilotriacetic acid (a chelating agent) } \\ \text { ORP } & \text { DOE Office of River Protection } \\ \text { PA } & \text { performance assessment } \\ \text { PNNL } & \text { Pacific Northwest National Laboratory } \\ \text { R\&D } & \text { research and development } \\ \text { RA } & \text { risk assessment } \\ \text { RCRA } & \text { Resource Conservation and Recovery Act of 1976 } \\ \text { Re } & \text { rhenium } \\ \text { SBS } & \text { submerged bed scrubbers } \\ \text { SEM-EDS } & \text { scanning electron microscopy-energy dispersive spectroscopy } \\ \text { SRNL } & \text { Savannah River National Laboratory } \\ \text { STADIUM } & \text { Software for Transport and Degradation in Unsaturated Materials } \\ \text { STOMP } & \text { (computer code) } \\ \text { STORM } & \text { Subsurface Transport Over Multi-Phases (computer code) } \\ \text { TRL } & \text { technology readiness level } \\ \text { WESP } & \text { wet electrostatic precipitators } \\ \text { WFQ } & \text { waste form qualification } \\ \text { WRPS } & \text { Washington River Protection Solutions LLC } \\ \text { WTP } & \text { Hanford Tank Waste Treatment and Immobilization Plant } \\ \text { XANES } & \text { X-ray absorption near-edge structure } \\ \text { XAS } & \text { X-ray absorption spectroscopy } \\ \text { XRD } & \text { X-ray diffraction } \\ \text { XRF } & \text { X-ray fluorescence } \\ & \end{array}$


SRNL-STI-2013-00002

PNNL-22103

Revision 1

\subsection{Introduction}

The Office of Environmental Management (EM) has tasked the Savannah River National Laboratory (SRNL) and the Pacific Northwest National Laboratory (PNNL) to jointly coordinate the engagement of the broader national laboratory community to bring the scientific and technological rigor needed to evaluate/prioritize alternatives, define/execute technology development opportunities, and inform decisions that will reduce technical and programmatic risks. SRNL and PNNL have strong knowledge of the EM mission needs and a long history of working with EM, U.S. Department of Energy (DOE) site contractors, other national laboratories, universities, and regulators to develop and deploy successful alternative solutions to many of EM's most challenging technical issues. Through a series of meetings among the national laboratories, site field offices, and site contractors; four initiative areas have been identified for possible national laboratory involvement with priority placed on the Low-Temperature Waste Forms/Technetium Removal and Waste Feed Acceptance initiatives. The laboratories utilized FY12 funding to initiate research and development efforts in this area and the Office of River Protection (ORP) subsequently provided FY13 funding to continue these efforts. To guide the investments in the low-temperature waste forms and technetium separations, PNNL and SRNL identified technology needs and issues associated with cementitious waste forms and technetium removal and identified approaches for addressing those needs and issues.

Low-temperature waste forms are being considered and used for solidification of large volumes of aqueous low-level wastes across the DOE complex. Frequently, these are cementitious waste forms, such as Saltstone being used at the Savannah River Site for immobilizing low-activity wastes, and Cast Stone, which was recently selected at Hanford for solidification of secondary wastes from the Hanford Tank Waste Treatment and Immobilization Plant (WTP). Cementitious materials are also being used to fill empty underground radioactive waste storage tanks as part of tank closure and are used in closure of contaminated facilities such as P and R Reactors at Savannah River and reactors and reprocessing facilities at Idaho.

In early FY12, a down-selection process led to the adoption of Cast Stone as the preferred method for solidification of aqueous secondary wastes from the WTP. That decision was preceded by a testing program funded through Washington River Protection Solutions (WRPS), in which national laboratories and academia were engaged in the development and testing of four lowtemperature waste forms, including Cast Stone, a phosphate-bonded ceramic known as Ceramicrete, fluidized bed steam reforming (FBSR), and an alkali-aluminosilicate geopolymer called DuraLith. That testing program provided key information for the down selection. In FY12, a design project moved forward with the development of a conceptual design for upgrades to the Effluent Treatment Facility (ETF) that will treat the secondary wastes and solidify them in Cast Stone. Planning documents were also prepared defining the work needed to develop the Cast Stone formulation for the secondary wastes, to support the design effort, to conduct waste form qualification activities to demonstrate that the Cast Stone waste form is acceptable for disposal in the Integrated Disposal Facility (IDF) at Hanford, and to support future performance assessments to address long-term health and environmental impacts resulting from waste disposal in the IDF. The secondary waste Cast Stone program has been on hold since FY13 pending rebaselining for the WTP. This provides an opportunity to mature the Cast Stone waste form for secondary wastes such that the information is available when the design effort resumes.

Another potential application for low temperature waste forms is as a supplemental immobilization technology for Hanford's Low-Activity Waste (LAW). The WTP LAW 
vitrification facility was not designed to process the entire volume of LAW retrieved at Hanford. Therefore, an additional supplemental LAW immobilization facility will be required. Up to two-thirds of all Hanford retrieved LAW may need to be immobilized in the supplemental LAW facility. Four candidate technologies are under evaluation (i.e., a second LAW vitrification facility, bulk vitrification, FBSR, and Cast Stone). Regardless of which supplemental technology is selected, the resultant LAW waste forms will be disposed of at the Hanford IDF.

The first three LAW immobilization options involve high-temperature processes, while Cast Stone represents a low-temperature process. The lower operating temperature for Cast Stone translates to the potential for lower construction and operating costs. WRPS is conducting a research and development program to understand the performance of Cast Stone as a LAW waste form utilizing significant national laboratory involvement. The breadth of the WRPS-led effort is discussed within Chapter 2 of this report, and is used to identify areas where national laboratory engagement would add benefit to DOE in advancing the use of Cast Stone to immobilize secondary waste streams at Hanford, aid their decision making process for supplemental LAW immobilization, and provide additional information for future performance assessments that will address cementitious waste forms.

Technetium-99 $\left({ }^{99} \mathrm{Tc}\right)$ is a long-lived radionuclide with an inventory estimate of about 26,000 curies in the Hanford tank wastes. Technetium is of particular importance because it has been shown, in performance assessments, to be a significant contributor to the potential long-term health and environmental impacts associated with disposal of secondary wastes and LAW in the IDF. The ${ }^{99} \mathrm{Tc}$ is found predominantly in the supernate fraction of the tank waste, the majority of which will be processed as LAW. In the LAW vitrification baseline process, the Tc is volatile at the processing temperatures of the LAW glass melter and the fraction of Tc that does volatize is captured in the off-gas treatment system. To increase the amount of Tc retained in the LAW glass, the off-gas condensates with the captured Tc are recycled to the LAW melter. ORP is focusing on means for capturing more Tc in the glass but some amount of Tc will likely still be emitted based on DWPF operating experience. Recycling the off-gas condensates to the melter to capture the volatile Tc has the impact of increasing the number of LAW glass containers produced and extending the duration of the WTP mission.

The principal technetium species found in LAW is the pertechnetate form $\left(\mathrm{TcO}_{4}{ }^{-}\right.$with an oxidation state of +7 ), which is highly soluble and readily mobile in groundwater. Due to its solubility, the majority of the ${ }^{99}$ Tc will be immobilized as LAW, with a smaller fraction immobilized as a secondary waste Cast Stone waste form. Therefore, it will remain on site at the IDF with only a small fraction shipped to a geologic repository with the immobilized high-level waste (IHLW). Past performance assessment prediction studies (see Mann, et al. 2003; DOE 2012) have shown ${ }^{99}$ Tc to be the primary groundwater dose contributor to the IDF Performance Assessment (PA). The performance period covered by both studies was 10,000 years, and the peak groundwater Tc concentrations arrive at the water table between 7,000 to 10,000 years after IDF closure. Due to its soluble nature and potential volatility during high-temperature vitrification processes, effective technetium management is important to the success of the overall River Protection Project mission. Removal of technetium from the LAW waste and immobilization or disposal by another means besides the LAW facility would eliminate a key risk driver for the IDF performance assessment.

One point emphasized by several of the National Academy of Sciences and National Research Council reports is that the performance of a nuclear waste disposal facility needs to consider the 
total system, including the facility (all of its engineered components) and the surrounding natural geologic environment when assessing risks and environmental impacts. If one focuses solely on performance of the waste form and attempts to evaluate risk and the fate of contaminants that release from the waste form itself, any perceived risks/impacts may be over-stated and lead to unnecessary mitigation activities. Conversely, the performance of a waste form itself may be detrimentally impacted by interactions with other engineered components or surrounding geologic materials, such that performance studies on the waste form itself may underestimate potential risk/environmental impacts. Therefore some of the proposed activities include leach and contaminant fate studies that include other disposal facility components. Further, some of the proposed activities include coordination and participation in overall disposal system performance assessment predictive conceptual model and numerical code development. Efforts on model and code development will be led by other organizations and programs (i.e., Advanced Simulation Capability for Environmental Management (ASCEM), Cementitious Barriers Partnership (CBP), and the IDF PA). However, it is important to establish close links between the model and code development and characterization/data collection efforts to ensure that the information obtained will be consistent with expectations for inputs and capabilities of the models.

The following section describes ongoing WRPS-funded projects that are investigating 1) the efficacy of Cast Stone as a supplemental LAW waste form and 2) technetium removal methods. After describing the ongoing WRPS projects, the next two sections describe data needs and issues in the area of 1) assessing the long-term performance of low-temperature waste forms and 2) technetium removal.

\subsection{Description of Ongoing WRPS Projects}

From 2009 through 2011, WRPS conducted a waste form testing program to evaluate lowtemperature waste forms for the solidification of aqueous secondary wastes to be generated at the WTP. That work led to the selection, in early FY12, of Cast Stone as the preferred waste form for immobilizing that waste stream. WRPS initiated a program in FY12 to further mature the Cast Stone solidification technology for Hanford LAW and a technetium separations technology for potential application to Hanford waste streams.

\subsection{Cast Stone}

As noted above, a cementitious waste form, known as Cast Stone, has been selected for the solidification of WTP aqueous secondary waste to be treated in the ETF. Based on that selection, a design project was started in FY12 to develop the conceptual design for facility modifications to ETF to provide the necessary capacity to treat the secondary wastes and to implement the Cast Stone process. That project was put on hold in FY13 pending schedule revisions for completion of the WTP. This provides an opportunity to mature the Cast Stone technology for secondary wastes such that information with respect to Cast Stone formulation, waste form qualification, and long-term performance is available to support the design effort when the design project and IDF performance assessment are continued in the near future. Cast Stone is also being considered to provide the required additional LAW immobilization capacity.

The Cast Stone waste form must be acceptable for disposal in the IDF. The Cast Stone waste form and immobilization process must be tested to demonstrate that the final Cast Stone waste form can comply with the waste acceptance criteria for the disposal facility and that the immobilization processes can be controlled to consistently provide an acceptable waste form product. Further, the waste form must be tested to provide the technical basis for understanding the long-term performance of the waste form in the disposal environment. These waste form 
performance data are needed to support risk assessment and PA analyses of the long-term environmental impact of the waste disposal in the IDF.

A testing program was developed in FY12 describing in some detail the work needed to develop and qualify Cast Stone as a waste form for the solidification of Hanford WTP secondary wastes (Westsik and Serne 2012). A similar testing program was developed for Cast Stone for Hanford LAW (Westsik et al. 2012). The FY13 LAW Cast Stone testing program was successful (Westsik, et al. 2013) in:

- Determining an acceptable formulation for the LAW Cast Stone waste form.

- Evaluating sources of dry materials for preparing the LAW Cast Stone.

- Demonstrating the robustness of the waste form for a range of LAW compositions.

The FY14 program objectives include:

- Demonstrating the robustness of the formulation for variability in the Cast Stone process.

- Providing Cast Stone contaminant release data and material properties in a form suitable to support PA and risk assessment evaluations.

- Evaluating the impact of the disposal environment conditions and long-term weathering of the LAW Cast Stone waste forms on contaminant retention.

The first step in determining an acceptable formulation for the LAW Cast Stone waste form was to conduct screening tests to examine expected ranges in waste composition, waste stream concentrations, dry-materials sources, mix ratios of waste (free water) to dry blend, and later, waste form curing conditions (e.g., temperature and relative humidity). A statistically designed test matrix was used to evaluate the effects of these key parameters on the properties of the Cast Stone as it is initially prepared and after curing. Results of the screening tests conducted in FY13 have been reported by Westsik, et al. (2013).

Later phases of testing are focused on final selection of the nominal Cast Stone formulation and demonstrating that Cast Stone can meet possible waste form requirements for disposal in the IDF. It is expected that this testing will use the results of the screening tests to define a smaller suite of tests to refine the waste loading in the Cast Stone formulation.

Preparation and testing of LAW Cast Stone containing actual radioactive wastes will be conducted to provide confirmation that the results observed with simulants in the screening tests and waste loading and waste form qualification (WFQ) testing are representative of what is expected with actual wastes.

An initial engineering-scale demonstration of the Cast Stone process and containerized waste form is underway at SRNL (Cozzi and Fowley 2013). A review of the results of this demonstration and characterization of the resulting waste form will continue into FY14.

Work is also planned to provide support to the risk assessment and future PAs by providing contaminant release data for the LAW Cast Stone waste form and evaluating the impact of IDF 
disposal environment conditions and long-term weathering of the LAW Cast Stone waste form on contaminant retention and release. To date, sufficient funds have not been available across the DOE to conduct this PA support work.

\subsection{Technetium Separations}

There has been considerable worldwide and DOE investment in technetium removal technologies, and the technical maturities of the Tc separation technologies range from the conceptual to deployed in the field. WRPS has chosen an elutable ion-exchange flow sheet using SuperLig ${ }^{\circledR} 639$ as the primary ion-exchange media to mature to potentially remove ${ }^{99}$ Tc from the LAW feed to supplemental immobilization. SuperLig ${ }^{\circledR} 639$ is a relatively mature technology and is highly effective at removing the pertechnetate fraction of technetium from the waste, and was extensively tested for application in the initial baseline for WTP prior to 2003 . However technetium in forms other than $\mathrm{TcO}_{4}^{-}$(non-pertechnetate species) has been identified in some actual waste samples, particularly those containing organic complexants. To underpin the potential impact of deploying a ${ }^{99} \mathrm{Tc}$ removal technology that only removes the pertechnetate fraction, it is essential to understand the quantity and distribution of the non-pertechnetate fraction within the Hanford tank waste system.

The scope of the Technetium Removal program will be to develop and mature a technetium removal concept to ascertain the benefits and risks associated with the removal of technetium from the LAW feed to supplemental immobilization. Current WRPS work is focused on evaluating and maturing the SuperLig ${ }^{\circledR} 639$ elutable ion exchange resin for the pertechnetate fraction and identifying strategies for dealing with the non-pertechnetate fraction.

WRPS is developing some conceptual flow sheets for LAW treatment and disposal that could benefit from technetium removal. One of these flow sheets will specifically examine removing Tc from the LAW feed stream to supplemental immobilization. The research and development (R\&D) that WRPS is pursuing is aimed at the following:

- Demonstrating that ${ }^{99} \mathrm{Tc}$ removal is cost effective and enhances the performance of all the candidate supplemental immobilization technologies,

- Validating a 'proof-in-principle, ${ }^{99}$ Tc removal concept to support inclusion of ${ }^{99}$ Tc removal in the Cast Stone program,

- Selecting and maturing a single ${ }^{99}$ Tc removal technology that is compatible with all the candidate supplemental immobilization technologies, and

- Developing a viable disposition pathway for ${ }^{99}$ Tc separated from the tank wastes.

The proposed flow sheet would utilize SuperLig ${ }^{\circledR} 639$ resin in an ion exchange configuration that would be deployed near tank. SuperLig ${ }^{\circledR} 639$ was extensively tested for deployment in the original Hanford WTP flow sheet (McCabe 2001). This polystyrene-based resin had very good selectivity for pertechnetate, and improved performance is observed with high potassiumcontaining feeds. The resin is eluted with warm water and can be reused. Testing for application with Hanford tank waste included radiation and chemical stability, radioactive sample performance, pilot-scale simulant performance, full-scale sluicing, computer modeling, and spent resin characterization. The FY13 work scope pursued by WRPS built off of this foundation. The original Tc flow sheet did not require near quantitative removal of Tc. Hence, the WRPS work 
scope will assess the removal efficiency and will expand the computational modeling of both the Tc isotherm and the ability to predict column performance.

Additionally, there was some variability in the SuperLig ${ }^{\circledR} 639$ resin batches that were used, with improvements occurring periodically throughout the seven years of testing. The resin does not swell significantly. Early batches of the resin did partially float in the high ionic strength LAW solutions, but the resin vendor was addressing this. The last batches of resin were received wet, which also helped with handling the material as the dry resin has very high electrostatic adhesion issues on surfaces. Throughout FY13, WRPS and SRNL have been working with the supplier to examine the supplier's ability to meet a new revision to the procurement specification on the resin's characteristics and performance.

Based on past testing, the resin does not remove non-pertechnetate forms of technetium, and this species will pass through the column uninterrupted. The pertechnetate fraction in these high-nonpertechnetate feeds is removed. There have been several studies that indicate varying amounts of non-pertechnetate concentrations in actual Hanford tank waste samples. Over the last year, PNNL has re-initiated testing to examine the potential non-pertechnetate structures, e.g., a technetium carbonyl species shown in Figure 2-1. The WRPS-managed scope that PNNL is performing includes preparation and characterization of this species along with understanding its stability in tank waste matrices. Additionally, PNNL plans to develop methods to quantify the amount of non-pertechnetate that exists in actual waste samples. This is to ensure an accurate quantification can be performed on future tank samples.

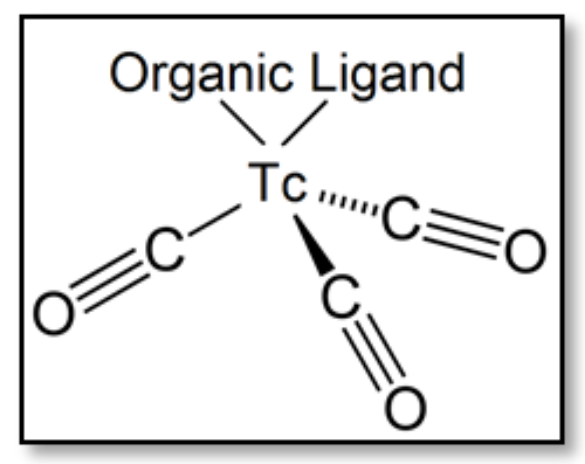

Figure 2-1. Technetium Carbonyl Species.

\subsection{Assessing Long-Term Waste Form Performance}

In its Engineering \& Technology Roadmap, DOE-EM identified a technical risk and uncertainty associated with assessing the long-term performance of waste forms (DOE-EM 2008). Specifically,

"Evaluating the performance of the integrated waste closure unit requires extrapolation of short-term performance data to extended periods of time. Current materials (i.e. glass, grout, etc.) are commonly used to immobilize highlevel and low-level radioactive wastes. Storage for extended periods of time (100's or 1,000's of years) is difficult to predict and leads to uncertainties in the long-term performance of the closure unit. Additional data and integrated approaches are needed to provide the necessary understanding of the behavior of the closure unit over the long-term so that appropriate strategies can be selected 
and so that performance assessments will be based on improved predictive capabilities.”

DOE-EM identified a strategic integration and crosscutting initiative to:

"Develop programs and approaches (including accelerated test protocols) to improve understanding of long-term waste form performance. Integrate the information gained with improved understanding of contaminant transport to enhance long-term risk assessment and predictive modeling capabilities.”

With this background, a number of recent relevant documents were reviewed to identify science and technology needs associated with conducting PAs and risk assessments (RAs) of waste form and disposal system performance. Included were reviews by the National Academy of Sciences (NAS 2009, 2010, 2011), the U.S. Nuclear Regulatory Commission review of the Saltstone PA (NRC 2012), previous Hanford PA and RA work (Mann et al. 2003; McGrail et al. 2003; Pierce et al. 2004), reviews by the Cementitious Barriers Partnership (CBP 2009a, 2009b, 2011; Sarkar et al. 2010, and Rustick et al. 2011), other technology risk reviews (Bredt et al. 2008), minutes from the recent Tank Waste Integration Workshop on Cementitious Waste Forms (Fox 2014), and summaries of recent, relevant studies by the national laboratories (Brown et al. 2014).

The science and technology needs identified were grouped into the following broad categories and summaries were developed:

- Hydraulic Properties

- Effective Diffusion Coefficients

- Solubility and $\mathrm{K}_{\mathrm{d}}$

- Cast Stone Formulation and Impact on Properties

- Impact of Curing Conditions and Scale on Cast Stone Properties

- Expected Fracturing in Cast Stone with Time

- Technetium Speciation and Impacts of Redox Changes

- Cast Stone Long-Term Weathering

- Multi-Component Interactions

- Cast Stone Contaminant Release Model-Conceptual and Numerical

- Uncertainty Analysis and Methodology for PAs

- Transformational Approaches for Waste Solidification.

There are overlaps among these broad categories. These can be resolved as the specific tasks to address the needs are defined.

Then, technical solutions to addressing the needs are presented. These solutions will be further refined as strong integrated teams of national laboratories, contractors, industry, and academia are brought together to provide the best science and technology solutions.

Finally, a preliminary evaluation of the significances and interfaces was conducted for each activity to address the technology needs, based on augmenting/supporting on-going Hanford Site activities. The initial evaluation of the significances/interfaces considered long-lead time activities to support pending data and technology needs, activities with multi-site benefit, and activities that have near-term importance because they may benefit the supplemental immobilization decision. 


\subsection{Hydraulic Properties}

Technology Needed: Hydraulic properties of a waste form are important inputs to flow and transport codes used to model contaminant transport from the waste form to the groundwater in support of disposal facility PAs and RAs. Density, pore-size distribution, moisture retention, and saturated and unsaturated hydraulic conductivities are needed for the Cast Stone waste form. While these properties are usually measured on laboratory-scale samples, data are also needed on waste form samples representative of the full-scale product including the impacts of curing temperature and relative humidity, and the use of admixtures. Data are also needed on the changes in hydraulic properties as the waste form weathers and cracks over the time span of the PA/RA. An additional challenge is that current methods to measure some of the key hydraulic properties are difficult to perform, time consuming (expensive), and the resultant measurements are often not readily interpreted because of method limitations/artifacts. For these reasons, the use of multiple techniques need to be investigated because obtaining an accurate estimate of the pore structure and hydraulic properties of multi-phase materials is extremely difficult for a single technique given the complexity of Cast Stone.

Approach: Investigate the efficacy/practicality of new methods to measure Cast Stone hydraulic and physical properties such as NMR, tomography, x-ray/neutron spectroscopy and dynamic pressurization methods on Cast Stone specimens.

A recent review article (Song 2007) describes the use of nuclear magnetic resonance (NMR) for characterization of porous materials, in particular as a bulk measurement technique for porosity and overall tortuosity. One form of NMR, decay due to diffusion (DDIF), allows determination of pore sizes but does not distinguish pore bodies and pore throats. On the other hand, conventional mercury porosimetry measures the distribution of pore throat sizes. A simple overlay of the two data immediately identifies pore body and the throat, thus obtaining a model of the pore space. Other researchers have used NMR techniques to spatially resolve and identify the development of hydration and porosity in the surface layers (top $50 \mathrm{~mm}$ ) of cementitious materials [McDonald et al. 2007; Korb 2009]. Both studies used nuclear magnetic relaxation methods at variable magnetic fields for continuous characterization of the evolving microstructure of various cementitious materials.

A combination of x-ray tomography, neutron tomography, and electrical resistance tomography will be studied to evaluate their strengths and weaknesses on providing detailed understanding of the size, distribution, and connectivity of pores within the Cast Stone waste form. Both x-ray and neutron tomography have recently been used to characterize the structure of cementitious materials and may have significant advantages over other imaging techniques. For example, $\mathrm{x}$-ray imaging can achieve spatial resolution down to micron and perhaps submicron size (a range needed to observe the Cast Stone pores); while neutron imaging can achieve a spatial resolution in the order of tens of microns. The use of both x-ray and neutron tomography on the same sample provides complementary information because of the fundamental differences in the interaction mechanisms with the materials. The differences in interaction mechanisms for x-rays (x-rays interact with the electron cloud) and neutrons (neutrons interact with the nucleus) provides a contrast between the two techniques. For example, neutron imaging is extremely sensitive to hydrogen and therefore can provide a more detailed image of the location and distribution of water filled pore spaces within cured and weathered Cast Stone samples.

Another technique that has been gaining in popularity is the use of electrical resistance tomography measurements to image changes in the pore structure of Cast Stone samples. 
Electrical resistance tomography is conducted by applying an electric current through electrodes and measuring the potential difference produced on the surface of the sample using electrode pairs. The ERT is an imaging modality used to estimate the internal conductivity distribution inside objects on the basis of current injections and voltage measurements acquired from the object boundary conditions. Similar to x-ray and neutron tomography, this is a non-destructive measurement that allow for a 3-D reconstruction of the sample to determine the location and distribution of pores.

The measurement of permeability by dynamic pressurization was developed for lower permeability concretes rather than the current method developed for compacted soils. Although less well-known, the dynamic pressurization method is potentially faster and more precise than the current methods. Dynamic pressurization can also be applied to the characterization of concrete containers. The method can use water, pore liquor, or other fluids as the permeating liquid. Variable sample sizes, including cored samples, can be accommodated with a single unit. The method is non-destructive so samples can be re-analyzed or used for additional analysis.

The CBP is continuing the development of an experimental method for determining the hydraulic conductivity of fractured cementitious materials under unsaturated conditions and the validation of the technique using samples with a known hydraulic conductivity. Preliminary method development was conducted by Kohn et al. (2012) who identified transient outflow extraction as the most promising method for characterizing the unsaturated properties of fractured porous media. While the previous research conducted focused on fractured media analogs such as stacked glass slides, an FY14 task focuses directly on fractured saltstone. ${ }^{1}$

Significance/Interfaces: The ability to be able to use state-of-art techniques to measure hydraulic properties on samples of Cast Stone produced at the small and large scale affords the DOE the opportunity to refine the PA/RA. The importance of this approach will increase assuming Cast Stone is selected as an alternative to LAW vitrification. It will, however, provide information concerning disposing of immobilized Secondary Wastes in IDF. The work could commence in support of Secondary Waste at any point. For LAW, however, there is an interface with the WRPS program that would delay starting on LAW samples till mid calendar year of 2012.

\subsection{Effective Diffusion Coefficients}

Technology Needed: In performance and risk assessments, contaminant release from cementitious waste forms are typically modeled as diffusion-controlled processes in which the contaminants diffuse through the porous waste form to the subsurface environment. Effective diffusion coefficients for each key contaminant are needed to conduct these calculations. Some effective diffusion coefficient data are available for Cast Stone through short-term leach tests conducted for up to 90 days. However, longer-term data are needed to provide confidence in the short-term test results. Effective diffusivities are usually measured on laboratory-scale samples; diffusivities are also needed on samples representative of the full-scale product including the impacts of curing temperature and admixtures used in production operations. Previous leaching tests have demonstrated that the effective diffusivities are sensitive to the waste composition and the waste concentration (waste loading) in the waste form. Additional data are needed for the range of waste compositions and waste loading for the Hanford LAW and secondary waste streams. Finally, information on the impacts of cracking in the waste form and weathering over

1 “Cementitious Barriers Partnership FY2014 Program Plan,” CBP-RP-2014-002, Draft. 
time on the effective diffusivities for cementitious waste forms is needed. Effective diffusivities are needed for contaminants including technetium, nitrates and nitrites, iodine, uranium, chromium and the other RCRA metals. For several of these species, the calculations are challenging because the concentrations in the leachates are at or below detection limits.

Approach: Extend Effective Diffusivity Measurements in Support of the LAW Supplemental Immobilization Testing Program and Expanded Secondary Waste Immobilization Tests.

Longer duration leach tests beyond the standard 63 to 90 days are needed to provide confidence that the shorter duration tests are representative of the long-term performance of the Cast Stone waste form. Selected Cast Stone monoliths are being leached during the LAW supplemental immobilization and secondary waste screening tests, waste loading, WFQ tests, and actual-waste activities beyond the 63-day standard test duration used in the EPA 1315 method. The monolith extended leach tests will continue with a solution replacement time period of 14 days and the replacement interval will be changed to ever increasing time periods (i.e., >14 days) based on making sure that enough mass of the key constituent Tc leaches during each time period that the concentration in the leachate is above detection limit values. In addition, some Cast Stone monoliths are being leached using IDF relevant leachates such as vadose zone pore water and simulated LAW glass leachate to evaluate the impacts of different chemical compositions on Cast Stone contaminant release.

Testing is needed with simulant waste streams spiked with equivalent concentrations of a nonpertechnetate form of technetium (likely an organic complex of reduced Tc (I or III) determined after consultation with tank chemistry experts-see Section 4.2) and processed into Cast Stone monoliths. The monoliths with Tc as pertechnetate and as non-pertechnetate will be leach tested using EPA 1315 methodology and effective diffusion coefficients compared. In addition to Tc, SRNL has performed testing with other redox sensitive contaminants, such as chromium, to understand oxidative effects on leaching. Recent work at SRNL in support of Saltstone (Langton and Almond 2013, Langton et al. 2012, Almond et al. 2012) and as part of the ORP Strategic Initiatives for Cast Stone (Langton and Almond 2013) has shown that oxidation front migration (and rate) into the waste forms can be studied using monolith sectioning and water leach testing of the sectioned waste form (after crushing). The assumption is that oxidized forms of $\mathrm{Cr}$ (to allow for non-radioactive testing) and Tc water leach quickly from the crushed material but reduced forms of $\mathrm{Cr}$ and Tc do not water leach. The Cast Stone work is continuing with samples being exposed to a range of environmental conditions (simulated in the laboratory) for extended time periods. Some Cast Stone monolith leach tests under unsaturated conditions may also be considered.

Significances/Interfaces: Long-duration activity important to IDF performance assessments. Benefits secondary waste Cast Stone and potential benefit to supplemental immobilization.

\section{3 $\underline{\text { Solubility and } \mathrm{K}_{\mathrm{d}}}$}

Technology Needed: Contaminants released from the waste form move through the engineered disposal system and the vadose zone sediments below by the movement of water infiltrating through these systems. The movement of the contaminants relative to the water movement can be slowed by interactions with the components of the disposal system and the sediments. In PA analyses, modeling the movement of contaminants through the engineered disposal system and the vadose zone includes a retardation factor (generally quantified by use of $K_{d}$ values) to capture this slower movement. The $\mathrm{K}_{\mathrm{d}}$ is contaminant and material specific. More data are needed 
regarding how the contaminants move through the sediments that experience the higher than natural $\mathrm{pH}$ conditions caused by the waste leachates. In particular, additional information is needed on how the $\mathrm{K}_{\mathrm{d}}$ for iodine and technetium are impacted by the disposal environment and the vadose zone below. For the IDF disposal facility environment, the travel time to the water table is highly sensitive to contaminant $\mathrm{K}_{\mathrm{d}}$. $\mathrm{K}_{\mathrm{d}}$ values as low as a few tenths of a mL per gram of Cast Stone can delay the arrival of the peak pore water concentration to times beyond the 10,000 year regulatory time period generally used for groundwater compliance comparisons (see Mann et al. 2003 for more discussion).

\section{Approach: Perform Additional Adsorption-Desorption Tests Using Cast Stone Leachates.}

The Cast Stone waste packages will be surrounded by other IDF waste packages (e.g., LAW glass) and Hanford formation sediments or other stand-alone vault components. The first adsorption tests will be classical batch adsorption tests and will be performed to investigate adsorption reactions among leachates from the Cast Stone waste form with the Hanford sediments. If warranted (based on system IDF PA predictions showing that the adsorption of key contaminants from Cast Stone waste packages is a sensitive process controlling the risk to groundwater and the accessible environment), flow-through column tests (both saturated and unsaturated water conditions) will be performed. Besides determining empirical $\mathrm{K}_{\mathrm{d}}$ values for key Resource Conservation and Recovery Act of 1976 (RCRA) metals, iodine (I) and Tc; surface complexation modeling and a sorption database, which accommodates the anticipated varying background geochemical conditions, will be constructed from the adsorption experiments and literature.

Significances/Interfaces: Key laboratory adsorption tests for I and Tc for near-term risk assessments and future IDF PA. High priority for out years should Cast Stone be selected as a supplemental LAW waste form.

\subsection{Cast Stone Formulation and Impact on Properties}

Technology Needed: The formulation of cementitious waste forms, specified by the waste composition; dry blend mix of cement, fly ash and blast furnace slag; and water to dry blend solids ratio, has been shown to impact the solidified waste form's properties. Previous performance and risk assessments for the Hanford tank waste disposal have had limited data available on the properties of the Cast Stone waste form especially as a function of the concentration of the liquid waste simulants. Hydraulic properties and effective diffusivities are needed over the ranges of expected waste compositions and waste loadings to be solidified in the Cast Stone. (The current Cast Stone Supplemental Immobilization project at Hanford and the ORP Strategic Initiatives are providing data to address this need for LAW; work is still needed for the WTP aqueous secondary waste stream.)

Approach: Expand Existing LAW Supplemental Immobilization Cast Stone Testing Program to Include Waste Chemistries Relevant to the Secondary Waste Stream.

As mentioned earlier, Cast Stone has been selected as the preferred waste form for immobilizing Hanford's WTP aqueous secondary waste stream. Like the immobilized low-activity waste (ILAW), the Cast Stone immobilized secondary waste will be disposed of in the IDF. However, specifications for the secondary waste Cast Stone waste form have not been established. A detailed testing plan has been developed to provide the technical basis for understanding the longterm performance of the secondary waste Cast Stone waste form in the IDF. However, because 
of funding constraints, this testing program has been indefinitely deferred. Fortunately, the testing required to evaluate the performance of the secondary waste Cast Stone waste form is consistent with currently funded activities within the supplemental LAW testing program. Given the similarities between the LAW and secondary waste streams, only a modest expansion to currently funded LAW supplemental immobilization testing program will be required to generate sufficient data to assess the performance of both (LAW and secondary waste) Cast Stone immobilized waste forms.

Significances/Interfaces: Important first step for all secondary waste Cast Stone work to follow.

\section{Approach: Cast Stone Production at High Sodium Concentration.}

The current Cast Stone flow sheet utilizes dry reagents including Portland cement (binding material), fly ash, and blast furnace slag (promotes reducing environment). The waste feed is mixed with the solid reagents and gravity-fed into containers for curing and disposal. To date, the testing performed with either simulated waste or actual waste had a sodium concentration around 5M. The Savannah River Site Saltstone facility originally operated between 3 and 7M sodium. Recent proposed changes in the salt processing flow sheets could further increase the sodium concentration. Increasing the sodium concentration reduces the overall volume of retrieved salt waste. This work will examine increasing the sodium concentration on Cast Stone production properties and radionuclide retention and release.

A study has been initiated through the ORP Strategic Initiatives to investigate Cast Stone formulated at high sodium concentrations (Fox, et al. 2013). The results showed that the Cast Stone slurries formulated at up to $10 \mathrm{M}$ sodium had fresh properties that should allow them to be successfully processed. After 28 days of curing, some of the simulated waste forms formulated at higher sodium concentrations had relatively low compressive strengths. These values improved after 90 days of curing. The measured leach indices for the various contaminants were fairly consistent among the twenty test mixes, demonstrating that the performance of the waste form is robust with respect to changes in the mix composition. Based on the initial positive results, SRNL recommended additional studies, including thermal analyses, determination of hydraulic properties, and evaluation of Tc-containing formulations.

Significances/Interfaces: Current LAW supplemental immobilization work is examining sodium concentrations to 7.8M. Provides technical bases for design work when ETF upgrades work resumes. Provides cost savings when work conducted in parallel to benefit both waste streams.

\subsection{Impact of Curing Conditions and Scale on Cast Stone Properties}

Technology Needed: Previous studies have demonstrated the potential impacts of curing conditions including humidity and curing temperature profile on the hydraulic properties of cementitious waste forms. Additional work is needed to characterize the impact of curing conditions on Cast Stone hydraulic and leaching properties. While curing conditions can be simulated in the laboratory, it is important to characterize samples from large-scale castings to confirm the observations and relationships determined at the laboratory-scale. Work to address this technology need will be integrated with related on-going work being conducted by the CBP. 
Approach: Curing Impacts with Focus on Microstructure and Controlling Porosity.

The measured porosity is related to salt solution loading in the waste form. Porosity can affect hydraulic conductivity of the waste form. It has not been determined how curing conditions influence the pore structure of the grout waste form. A task to evaluate effects of variables such as the presence of undissolved solids (in the form of precipitated salts) ability to obstruct pores and hinder hydraulic conductivity or the controlling of the waste form container temperature and atmosphere to modify the pore structure to better retain contaminants of concern or hinder hydraulic conductivity is proposed. An FY13 saltstone study (Papathanassiu et al. 2013) confirmed earlier results (Reigel et al. 2012) demonstrating that the hydraulic conductivity of simulated saltstone is improved when the waste form is cured at high relative humidity.

The effects of temperature rise on the microstructural evolution of Cast Stone have not been determined. A task to evaluate effects of temperature rise in the waste form container on the resulting microstructure and mineralogy of the waste form and the relation to other waste form properties will lead to a better understanding of the effects of waste form composition and temperature on the microstructural development of the Cast Stone waste form.

Significances/Interfaces: Important design consideration for Cast Stone Hanford secondary wastes. Longer-term benefit to IDF performance assessment and LAW Cast Stone if it is selected for supplemental immobilization.

\subsection{Expected Fracturing in Cast Stone with Time}

Technology Needed: Cementitious material monoliths are expected to develop both micro and macro cracks over time as the waste forms age and are impacted by natural processes such as carbonation, delayed ettringite formation, and disposal facility weathering forces. It is generally accepted (see Langton 2012 and Pabalan et al. 2009) that macro cracks are the type of cracks that need to be addressed, especially those distributed throughout the waste form matrix. The recent crack literature review (see Langton 2012) suggests that the largest knowledge and data need is the study of contaminant transport out of waste forms that are partially saturated with moisture. Further, studies on gas transport in cracked concrete/cement are very limited. This knowledge and data need relates to the oxidation front discussion in Section 3.7 below.

PA analyses need to consider the timing and extent of macro cracking and the impacts of both the moisture content of the waste form and the surrounding environment. Data are needed on how hydraulic and leaching properties of the waste form change with the extent of cracking and the moisture content of the system. Work is also needed to evaluate the potential for secondary precipitates, such as calcium carbonates, to fill cracks in the waste forms over time and the resulting changes in hydraulic and leaching properties. Work to address this technology need will be integrated with related on-going work being conducted by the CBP.

\section{Approach: Effect of Carbonation Reactions.}

Cement-based waste forms are known to react quickly with carbon dioxide present either in the air-filled portion of the vadose zone pores or dissolved as bicarbonate and carbonate anions in the pore waters. The carbonation chemical reactions have fast kinetics and produce various forms of calcium carbonate that evolve in the following order: amorphous $\rightarrow$ vaterite $\rightarrow$ calcite. Under some circumstances, the calcium carbonate solids fill pores, heal micro cracks, and coat the outer 
surfaces of cementitious waste forms. Under different circumstances, the calcium carbonate solids that form may induce cracks or increase internal porosity by using up calcium from dissolution of the more voluminous calcium silicate gels and portlandite $\left[\mathrm{Ca}(\mathrm{OH})_{2}\right]$. Therefore, the carbonation process can have beneficial or detrimental impacts on the Cast Stone porosity (i.e., either reducing or increasing porosity), which in turn influences the diffusion of contaminants dissolved within the Cast Stone internal pore water toward the outside of the waste forms. The literature on carbonation will be critically reviewed for geochemical environments germane to the IDF subsurface disposal system in an attempt to determine which effect predominates. Based on this literature review, an experimental program will be implemented to further characterize the impacts of the carbonation reactions in cementitious waste forms. Work to address this technology need will be integrated with any related on-going work being conducted by the CBP.

Significances/Interfaces: The literature review is important as a precursor to long-duration studies needed to support future performance assessments. The importance of additional laboratory testing on the effects of carbonation will be deferred until the literature results are evaluated.

\section{Approach: Effect of Sulfate Attack and Ettringite Formation.}

There is a wealth of information in the cement/concrete literature on the detrimental impacts of high concentrations of sulfate reacting with hardened cement to cause expansion and cracking via the formation of the mineral ettringite $\left[\mathrm{Ca}_{6} \mathrm{Al}_{2}\left(\mathrm{SO}_{4}\right)_{3}(\mathrm{OH})_{12} \cdot 26 \mathrm{H}_{2} \mathrm{O}\right.$ ]. In the cement system, whether and when during the setting process ettringite forms depends on the ratio of calcium sulfate to tricalcium aluminate (C3A); when this ratio is low, ettringite forms during early hydration and then converts to the calcium aluminate monosulfate (AFm phase or $\left(\mathrm{Al}_{2} \mathrm{O}_{3}-\mathrm{Fe}_{2} \mathrm{O}_{3}-\right.$ mono)). When the ratio is intermediate, only a portion of the ettringite converts to AFm and both can coexist, while ettringite is unlikely to convert to AFm at high ratios. Because ettringite has a large molar volume compared to most other cement solid phases, when significant amounts form after cement has nearly or fully completed its setting, the newly formed minerals can cause expansion and cracking in the solid matrix. This leads to crack formation and the loss of physical stability/strength. In Cast Stone waste forms, the cracking can lead to increased release of contaminants via diffusion processes and the increased access of leachant solutions to the internal volume of the waste form. The literature on sulfate attack will be critically reviewed to ascertain whether the sulfate present in the liquid wastes, naturally present within the three dry-blend ingredients, and in the vadose zone pore water are high enough to cause ettringite formation after initial set of the Cast Stone. If there is sufficient sulfate present to raise concerns about ettringite formation, an experimental program will be implemented to further characterize the ettringite formation process and its impacts on Cast Stone waste forms in the IDF disposal environment. Work to address this technology need will be integrated with any related on-going work being conducted by the CBP.

Significances/Interfaces: The literature review is an important precursor to long-duration studies needed to support future performance assessments. The importance of additional laboratory testing on the effects of sulfate attack and ettringite formation will be deferred until the literature results are evaluated.

Approach: Effect of Aging. 
Much work has been documented in the cement/concrete literature on the effects of aging on performance of concrete, however, the presence of salts and the absence of aggregate, significantly reduces the available literature applicable to the understanding of the ageing process on properties of salt-bearing waste forms. The literature on aging of cementitious materials will be critically reviewed for the impacts of salts on aging and materials properties.

Significances/Interfaces: The literature review is a precursor to long-duration studies needed to support future performance assessments. The CBP has identified cracking associated with ageing as a topic for additional study.

\subsection{Tc Speciation and Impacts of Redox Changes}

Technology Needed: Cast Stone includes blast furnace slag (BFS) in the dry blend mix. One role for the BFS is to reduce technetium present in the wastes to the less mobile Tc(IV) oxidation state. Technetium release rates have been shown to be significantly lower for the reduced state of Tc compared with the oxidized state (Tc(VII)). Short-term leach tests typically determine the effective diffusivity for Tc in this less mobile form. Over time, oxygen from infiltrating vadose zone water and from the air is expected to penetrate into the waste form and re-oxidize the Tc to the more mobile $\mathrm{Tc}(\mathrm{VII})$ form. Cracking of the waste form may increase the pathways for oxygen to penetrate the waste form and thereby increase the rate of re-oxidation. Information is needed to determine the reductive capacity of the final Cast Stone waste forms and all of the dry blend components as well as the liquid wastes themselves. The ability of the waste form to maintain the Tc in the reduced state for time periods of thousands of years needs to be supported using modeling predictions based on measurements of the growth of the oxidation front and rate of re-oxidation as changes to the cementitious waste forms due to weathering and cracking occur over time. Effective diffusivities need to be determined for both the Tc(IV) and Tc(VII) oxidation states. Technetium speciation studies could show that the Tc is incorporated into the crystalline structure of one or more of the cement phases such that is not susceptible to reoxidation over time.

\section{Approach: Cast Stone Technetium Speciation Characterization.}

To have confidence in the long-term performance of solidification waste forms such as Cast Stone, it is important to understand how the constituents of concern are retained in the waste form and how they are released when exposed to water in the disposal environment. Characterization of the solid phases that comprise the Cast Stone waste form and the chemistry of the contaminants within the Cast Stone provide insights into how the contaminants are retained and released. This then enables extrapolating short-term leach tests to long-term waste form performance. Samples of both unleached and leached Cast Stone monoliths from both the LAW and secondary waste streams containing either pertechnetate or non-pertechnetate Tc spikes will be characterized for Tc speciation using synchrotron-based x-ray absorption spectroscopy, total composition, mineralogy, and redox capacity. Finally, actual-waste Cast Stone monoliths will be characterized in similar fashion if the total Tc in the Cast Stone is high enough to characterize using synchrotron based x-ray absorption spectroscopy.

The chemical composition of the Cast Stone monoliths will be determined, both before and after leaching. This characterization information is required to quantify the starting mass (and activity for key radionuclides in the solidified actual waste) of each analyte in the Cast Stone, which is a needed parameter to calculate the effective diffusion coefficients. For Cast Stone waste forms that are chosen for extended leach testing, at least one of each waste type will also be 
characterized for final composition at the end of the leach testing to aid in understanding the longterm evolution of the Cast Stone chemistry and the residual constituent content.

The redox capacity of selected LAW and secondary waste Cast Stone waste forms, both before and after leaching, will be determined using redox capacity measurements. The difference in the redox capacity after leaching is related to oxygen influx and consumption of redox capacity, and will be used to develop a simple conceptual model of the rate at which the oxidation front penetrates into Cast Stone monoliths when saturated with water. If there are enough Cast Stone monoliths available, several will be stored in air for different time periods and then subjected to the same redox capacity measurements to develop a similar conceptual model for the rate of oxidation-front penetration in air. The results will also be used to understand the changes in Tc speciation and oxidation state in the Cast Stone.

Selected unleached specimens of each of the Cast Stone waste formulations will be characterized for bulk mineralogy using x-ray diffraction (XRD) and scanning electron microscopy-energy dispersive spectroscopy (SEM-EDS). For Cast Stone waste forms that are chosen for extended leach testing, selected samples will also be characterized using the same techniques to determine the final mineral composition at the end of the leach testing to aid in understanding the long-term evolution of the Cast Stone mineralogy.

Significances/Interfaces: Long-duration studies needed to support IDF performance assessments of actual disposal conditions. Benefits secondary waste Cast Stone and potential benefit to supplemental immobilization and other DOE sites using cementitious waste forms.

\section{Approach: Characterization of the Technetium Oxidation Front for Cast Stone.}

A SRNL Saltstone monolith sectioning approach for measuring an oxidation front based on leaching of spiked contaminants has recently been developed (Almond et al. 2012). Chromium $(\mathrm{Cr})$, vanadium $(\mathrm{V})$ and rhenium (Re) were evaluated as oxidation-reduction tracers in the Saltstone sample using laboratory-cured samples. The premise of this method is that the oxidized form of these tracers is soluble and therefore leachable, whereas the reduced form is insoluble and does not significantly dissolve in the leachate. This same method can be applied to laboratoryproduced samples of Cast Stone or field-cured samples and initial work has commenced. Cast Stone samples containing $\mathrm{Cr}$ or Tc spikes are also being exposed to oxygen saturated water or air in different tests for a period of time up to 1000 days. The sliced wafer samples will be ground under conditions that would not oxidize the three-redox sensitive elements leached in de-aerated de-ionized water under inert atmosphere conditions. Preliminary results show the V and Re are not useful indicators of oxygen front migration into saltstone but that both $\mathrm{Cr}$ and $\mathrm{Tc}$ leaching of depth discrete sections from exposed monoliths appear to be generating similar useful measures of the oxygen re-oxidation front. More studies on saltstone cured at different times and exposed to air or oxygen-saturated water are needed to quantify the re-oxidation front and its rate of progression into monoliths.

Additional studies of depth discrete leaching with simulated saltstone (Papathanassiu et al. 2013) and Cast Stone (Langton and Almond 2013) waste forms have indicated that Cr may not be an appropriate surrogate for Tc in oxidation front determinations, although it has been useful for method development efforts. Preliminary depth discrete leaching experiments were completed with Tc-spiked samples, and sample exposures under a variety of environmental conditions continue (Langton and Almond 2013). 
Significances/Interfaces: Long-duration studies needed to support IDF performance assessments in actual disposal conditions. Benefits secondary waste Cast Stone and potential benefit to supplemental immobilization and other DOE sites using cementitious waste forms.

\section{Approach: Leaching of Non-Pertechnetate Technetium from Cast Stone.}

PNNL is examining historical waste tank analysis data (see Section 4.2) to determine if the quantity of non-pertechnetate fractions in the Hanford inventory can be estimated or correlated with other species. PNNL is also working on synthesizing a non-pertechnetate species that would be stable in the alkaline tank waste. The purpose of this work would be to determine the Tc leach rate from a series of Cast Stone samples produced with LAW waste simulants spiked with nonpertechnetate Tc and comparing the leach results with similar Cast Stone samples made with pertechnetate spiked simulants. In addition, actual tank waste samples that have been archived will be speciated to determine the non-pertechnetate fraction prior to use. If the speciation of Tc is successful in the actual wastes, then Cast Stone monoliths will be made and leach tested. Leachates from the actual waste-Cast Stone samples will also be speciated to determine if the pertechnetate or non-pertechnetate form is the one leaching.

Technetium speciation in the Cast Stone waste forms made with the actual waste and some of the Cast Stone waste forms that are chosen for extended leaching will be determined on both unleached and post-leached specimens. Preliminary work in this area is underway. The technetium speciation will be determined on Cast Stone waste forms that contain at least $100 \mu \mathrm{g}$ ${ }^{99} \mathrm{Tc} / \mathrm{dry}$ g of Cast Stone using a combination of micro-XRD, micro-X-ray fluorescence (XRF) and synchrotron x-ray absorption spectroscopy (XAS).

Significances/Interfaces: Long-duration studies needed to support IDF performance assessments. Benefits secondary waste Cast Stone and potential benefit to supplemental immobilization.

\subsection{Cast Stone Long-Term Weathering}

Technology Needed: Performance assessments and risk assessments typically evaluate the performance of the waste form and disposal facility for time periods spanning thousands of years. The long-term stability of Cast Stone over these long times is not known. Within the disposal environment, the cementitious waste forms will be exposed to air containing oxygen, which can change the redox chemistry of the several contaminants, and carbon dioxide that can lead to carbonation reactions within the waste form. Over time, infiltrating vadose zone pore waters will change the chemistry of the interstitial pore water in the grouts from a caustic $\mathrm{pH}$ to a more neutral $\mathrm{pH}$ and will also bring additional oxygen and carbonates into the system. Carbonation reactions and ettringite formation will change the pore structure of the waste form and may induce cracking. Whether or not chemical reactions associated with aging of Cast Stone would positively or negatively impact its long-term performance is unknown and needs to be investigated. A better understanding of these aging processes is needed, and the impacts to the waste form hydraulic and leaching properties needs to be characterized. Work is also needed to address the initial relatively rapid release frequently observed during the first several days of leach tests that is excluded from calculated release rates. Work to address this technology need will be integrated with related on-going work being conducted by the CBP.

Approach: Accelerated Test Method Investigations. 
Numerous review panels have noted the dilemma that short-term experiments are not well accepted as a means of predicting the long-term release of key contaminants from cementitious waste forms. There have been recommendations to explore accelerated weathering tests (as long as the mechanisms of contaminant release and cement secondary mineral formation do not change) to bolster the tie between short and long-term performance.

In Um et al. (2011), the use of elevated gas concentrations of $\mathrm{CO}_{2}$ and $\mathrm{O}_{2}$ in controlled atmosphere chambers under varying relative humidity was investigated. Cast Stone monoliths and (sand to small gravel sized) pieces made with Tc-spiked secondary waste simulants were subjected to one of the elevated gas concentrations for short time periods (up to one month). The "accelerated" weathered monoliths were then leach tested using EPA 1315 methods and results compared to monoliths that were not "accelerated-weathered". There were significant differences observed in contaminant leach rates, leachate $\mathrm{pH}$ and chemical composition. In addition other measurements such as Cast Stone porosity and pore size distribution, mineralogy, and Tc valence state measurements were performed on both unleached and leached specimens under normal and accelerated weathering conditions. The data set was limited as was the variation of accelerated weathering times and elevated gas and relative humidity. Therefore more systematic testing of this method of accelerating carbonation and re-oxidation processes will be performed.

Significances/Interfaces: Requires knowledge gained from results of other leaching mechanism and waste form weathering studies to develop credible accelerated test methods. Benefits secondary waste Cast Stone and potential benefit to Cast Stone LAW supplemental immobilization.

\section{Approach: Porosity Changes with Weathering.}

Because key Cast Stone weathering processes change with different stages of the cement hydration and diagenesis, developing an understanding of the microstructure evolution of the Cast Stone pores (such as total porosity, pore size [diameter] distribution, pore throat size and shape, and pore connectivity) and the influence of geochemical changes (such as hydration, mineral replacement reactions, [calcium-silicate-hydrate, calcium hydroxide, calcite and ettringite formation], and redox) on these pore-scale processes is critical to predicting contaminant release from the Cast Stone waste form.

Currently, based on some empirical studies, waste form scientists believe that a major factor controlling radionuclide release rates, specifically for redox-sensitive contaminants such as ${ }^{99} \mathrm{Tc}$, is oxygen diffusion into the pore structure of the Cast Stone as it ages with time. The rate of oxygen diffusion can change as a result of an increase or decrease in the pore diameter, pore connectivity, or the formation of stress cracks caused by the mineral replacement reactions, such as ettringite formation. Therefore, to improve the technical basis for the time-dependent changes observed in short-term leaching experiments, to reduce the use of conservative approaches, and to provide more credible estimates of radionuclide release, fundamental information on the key processes controlling Cast Stone pore-structure evolution and its relationship to Cast Stone geochemistry is required.

Although the bulk release measurements derived from Cast Stone monolith leach tests such as the EPA 1315 method provide some insight into the factors that affect contaminant release, the 
missing critical link - gathering quantitative data on pore-scale changes driven by geochemical reactions-limits the development of more accurate PA models. The mass transfer of contaminants (e.g., ${ }^{99}$ Tc diffusivity) from the Cast Stone waste form's pore water, and subsequently out of the solid waste form, is directly related to the number and size distribution of pores as well as the pores' microstructure (i.e., the pore tortuosity and connectivity). Therefore some scouting activities will be performed in the early years of the project to investigate which instrumentation and methods can provide quantitative information of the pore structures and their evolution during Cast Stone weathering. Multiple techniques will be used because obtaining an accurate estimate of the pore structure of a multiphase material such as Cast Stone is extremely difficult with a single technique. These measurements will include: mercury porosimetry, Brunauer-Emmett-Teller (BET)/Barret-Joyner-Halenda (BJH) methods, tomographic measurements (x-ray, neutron, and electrical resistance tomography), and small-angle neutron scattering with contrast variation. Each technique is designed to provide complementary information on the pore-scale changes before and after leaching.

Significances/Interfaces: Long-duration studies needed to support IDF performance assessments. Benefits secondary waste Cast Stone and potential benefit to supplemental immobilization.

Approach: Examining Lysimeter Behavior for Tc in Cast Stone Samples.

In order to understand the behavior of Tc incorporated into a Cast Stone waste form under actual environmental conditions, samples of Cast Stone produced from simulated and actual tank waste will be buried in a lysimeter facility. The lysimeter will be filled with well-mixed subsurface sediment. Periodically, leachate samples from the lysimeter will be collected and analyzed for Tc. The Tc data will be examined using a number of different models to determine the leach rate from the Cast Stone. Note that initial planning for these studies began during FY13, although funding limitations prevented the studies from starting. At the conclusion of the lysimeter testing, the Cast Stone Sample will be recovered and characterized using a number of spectroscopic techniques. Lysimeter tests in arid environments require a commitment potentially spanning several decades.

Significances/Interfaces: Requires secondary waste Cast Stone formulation work as a precursor. However, because the time for field lysimeter tests to start yielding leachate can be several years, fabricating the waste forms and placing them in the lysimeter as soon as possible merits consideration. The importance of performing field lysimeter tests with Cast Stone is high assuming Cast Stone is accepted as a supplemental LAW waste form. Lysimeter work at Savannah River was used successfully to gain stakeholder acceptance of Saltstone disposal.

Approach: Development of a Test Method to Demonstrate Equivalent Durability.

Technetium leaching is a primary concern in HLW borosilicate glass. Testing performed in the development of the glass waste form identified boron release as a bounding representation for the leaching of technetium. Boron leaches from HLW glass at a rate similar to technetium without forming back phases from precipitation. This is the basis for the ASTM C 1185 Product Consistency Test. Low-temperature waste forms require a uniform test or tests that can adequately represent the release of technetium leaching in the waste form. 
This task will work to identify/develop a leach test method for characterizing the leaching/ weathering of cementitious waste forms. The test method will be of short duration so that it can be used as a product quality check method and that could be used as a specification for the disposal facility waste form acceptance criteria.

Significances/Interfaces: Need to invest first in better understanding long-term weathering of Cast Stone before developing an applicable new test method. Direct tie with accelerated test method evaluations.

Approach: Literature Review on Natural Analogs and Ancient Cements.

Natural analog studies, as considered by the International Atomic Energy Agency (IAEA 1989),

"involve the use of the analogy approach to investigate natural occurrences of materials, conditions and processes which are the same or similar to those known or predicted to occur in some part of a disposal system.”

Using a definition modified from that given by Cadelli et al. (1988, p. 264),

"a natural analogue may be defined as a natural geologic system in which one or more processes similar to those that may exist at a potential disposal facility and/or induced by the storage of radioactive wastes are thought to be operating over long time periods or spatial scales.”

Both of these definitions suggest that natural analogs are in fact long-term natural experiments involving natural or man-made materials in an environment uncontrolled by man. Some researchers further distinguish between natural analogs and anthropogenic (or historical) analogs; however we will look for both types of natural analogs for Cast Stone.

A typical study of a natural analog, for example, might be the measurement and analysis of the subsurface dispersion of uranium and other trace elements associated with a uranium ore deposit. Studies of anthropogenic analogs, on the other hand, may include the evaluation of processes affecting the survival of archaeological artifacts, ancient metals, concretes, or clay barriers in natural settings. Anthropogenic analogs may also include sites where past waste-disposal practices and/or equipment-testing activities (e.g., detonation of nuclear explosive devices) have resulted in the release of radionuclides to the natural environment. Studies of such sites provide process information for the migration of trace elements, such as radionuclides, over long time periods and/or large spatial scales.

The natural analog literature germane to cementitious waste forms will be critically reviewed to extend the knowledge base on cement weathering processes to long times. Natural analogs for cementitious materials have been reviewed/discussed in a few publications such as Appendix $\mathrm{C}$ in Krupka and Serne (1998). Other reports that are available on the weathering of archaeological cements/concrete include Aloy et al. (2008), Roy and Langton (1989), and Langton (1980). There are also numerous articles on a high-pH and high-alkaline groundwater system in Maqarin, Jordan, that is used to address the long time evolution of cement pore waters in subsurface environments (Linklater et al. 1996). Other locations in Jordan and Yemen also have subsurface environments similar to weathered cement that have been compared to long-term PA predictions for the evolution of concrete and cement in nuclear waste repositories (Smellie and Karlssson 
1997; Smellie et al. 1997; Worden 2006). These references and others cited within them, as well as others found in a comprehensive literature search, will be critically reviewed. Electronic databases will be searched for other natural analog documents pertaining to buried cement waste forms.

Significances/Interfaces: The literature review is important as a precursor to long-duration studies needed to support future performance assessments.

\subsection{Multi-Component Interactions}

Technology Needed: The Cast Stone waste package will include the Cast Stone waste form inside a steel container. In the disposal system, the corroding steel microenvironment may produce localized reducing conditions that affect the mobility of contaminants by forming lesssoluble solids containing the redox-sensitive contaminants. Over the long time periods evaluated in PA and RA analyses, the presence of the steel container is usually ignored. There may be some benefit in considering the presence of the steel and its additional reductive capacity and the resulting impacts on the maintenance and re-oxidation of technetium in the reduced oxidation state. Further, the corrosion products, amorphous and crystalline ferric oxides, are high capacity adsorbents for most cations at the alkaline $\mathrm{pH}$ of cementitious and glass leachates.

\section{Approach: Waste Package Release Testing.}

The waste form tests required to support long-term risk assessment and PA start with wellconstrained tests conducted on the Cast Stone waste form itself. These tests would include water leach tests and accelerated weathering tests that evaluate physical and mineralogical properties of the Cast Stone. Tests then progress to multi-component tests that include the impacts of waste container, other co-disposed waste forms, and the surrounding vadose zone sediments. Each test is used to a) identify the final solid phases and minerals formed by interaction of the starting solids with water and gases present in the surrounding sediment pores (i.e., the weathering process), b) identify a reaction network (the key minerals that form and the sequence of formation) for the Cast Stone waste form and waste package, or c) obtain the values for parameters required in the diffusive release or kinetic rate law equations or thermodynamic solubility and precipitation equations used by the waste form release algorithm to quantify the release of major and minor constituents in the Cast Stone waste form.

The chemical impacts of the (a) metal containers in which the Cast Stone waste form will be poured and (b) the surrounding vadose sediments will be determined in multi-component column leach tests. In one suite consisting of three tests, the bottom of the column will be filled with a layer of Hanford formation sediment then a thin layer of granular metal particles will be placed on top of the sediment and below a thicker layer of crushed Cast Stone replete with all RCRA metals, ${ }^{99}$ Tc and ${ }^{127} \mathrm{I}$ that in turn is covered by a layer of Hanford sediment. Simulated vadose zone pore water will be slowly percolated up flow through the packed column and the leachate collected as a function of time. The resultant leachate will be compared to two other such packed columns that consist of 1) a layer of similar crushed Cast Stone sitting on top of the Hanford sediment and 2) a packed column with a layer of Hanford sediment followed by the layer of crushed Cast Stone followed by the top layer of Hanford sediment. The three multi-component flow-through leach tests will allow study of the impacts of the metal container and surrounding Hanford sediments on the release of key contaminants from the Cast Stone. 
The metal container in the early stages of leaching should promote reducing conditions before the metal is totally oxidized and likely slow transport of redox sensitive contaminants such as Tc. The packed column with a top layer of Hanford sediment above the crushed Cast Stone may adsorb some of the leached contaminants and delay their appearance and reduce their concentration in the leachate. To support the risk assessment and future more detailed PA, the transport properties of contaminants within the entire Cast Stone waste package and surrounding sediments need to be understood to estimate release from the waste package to the disposal system.

Besides monitoring the leachates from these types of up-flow tests, at the end of the test the various packed layers would be carefully removed and the solids characterized for mineralogy and total chemical composition including the contaminants of interest. Similar multi-component tests would be conducted with the leachant being simulated LAW glass leachate being pumped slowly up-flow through the packed columns. If the combined tests with Cast Stone, granular metal container, and Hanford sediments show that additional minerals form and control the release of contaminants from the Cast Stone waste form, these minerals will be included as end products in the overall IDF geochemical conceptual model.

Significances/Interfaces: Requires secondary waste Cast Stone formulation work as a precursor. However, because the time for these component interaction tests to start yielding leachate can be several years, initiating the tests as soon as possible merits consideration. Studies needed to support IDF performance assessments. Benefits secondary waste Cast Stone and potential benefit to supplemental immobilization.

\subsection{Cast Stone Contaminant Release Model-Conceptual and Numerical}

Technology Needed: There is no fundamental scientific reason that empirical diffusion coefficients based on short-term laboratory tests for each contaminant accurately describes Cast Stone performance for 10,000 years. Cementitious waste forms, such as Cast Stone, are inherently a porous medium and so diffusion, advection, and chemical reactions within its pores can all be treated within the framework of reactive transport theory (Steefel and Lichtner 1998). Cementitious materials and waste forms have been considered in modeling for a number of risk assessments and performance assessments supporting waste disposal, tank closure and in situ closure of decommissioned facilities like reactors and reprocessing facilities (see for example, CBP 2009a; Flach et al. 2009; Denham and Millings 2012). Modeling approaches with a variety of levels of complexity for fate and transport have been used, primarily representing geochemical considerations with $K_{d}$ or solubility-limit approaches. The assumptions for $K_{d}$ or solubilities are underpinned with some combination of empirical data and/or geochemical calculations, but the calculations have typically not included direct consideration of reactive transport. Computer codes that are part of the CBP (e.g., LeachXS ${ }^{\mathrm{TM}}$ and STADIUM $^{\circledR}$ ) have also been used to consider reactive transport of constituents to address the evolution of cementitious materials over time. There is also an example of the use of STORM with reactive transport to model uranium and ${ }^{14} \mathrm{C}$ release from a grout disposal facility in Italy (Bacon et al. 2002; Buck et al. 2002). The chemical aging reactions and contaminant transport in cementitious forms are inherently coupled and so a reactive transport approach is well suited for modeling long-term degradation and contaminant release from Cast Stone. Work to address this technology need will be integrated with related ongoing work being conducted by the ASCEM program and the CBP.

Approach: Choose/Improve Existing Mechanistic Based Cementitious Waste Form Release Conceptual and Numerical Codes. 
Future IDF PA activities would benefit from improving the conceptual and numerical models for waste form release/radionuclide source terms. Cast Stone contaminant release conceptual models used at Hanford have been solely based on empirical diffusion-controlled release. Moving forward, these should be updated based on the combined chemical and physical conceptual models. Such conceptual models are promoted by the CBP. CBP is in the process of melding a suite of conceptual and numerical models that incorporate physical cracking as well as solubilityprecipitation along with diffusion dominated mass transport. The CBP suite of computer codes (LeachXS ${ }^{\mathrm{TM}}$-ORCHESTRA-STADIUM-GoldSim) is one viable option for improving the waste form release models. A second option is the Subsurface Transport Over Multi-Phases (STOMP) code has been used for PA activities at Hanford and is the current code used for the 2005 IDF PA. Should the STOMP code continue to be used, certain improvements should be added such as 1) add thermodynamic data for key cementitious solid-solution phases available in the ORCHESTRA thermodynamic database, and 2) add the impacts of cracking, re-oxidation of redox-sensitive contaminant of concerns and oxidation of residual BFS, and carbonate weathering available in the Software for Transport and Degradation in Unsaturated Materials (STADIUM ${ }^{\circledR}$ ) code. The ASCEM project includes a tank waste demonstration that includes considerations related to the evolution of cement based materials over time and reactive transport in cementitious material and waste tanks. Additional activities have also been proposed to consider releases from cementitious waste forms. In order to address the evolution of cementitious materials and potential releases from cementitious waste forms, the ASCEM project could include activities to incorporate or establish links with data in the ORCHESTRA and STADIUM codes.

Significances/Interfaces: Requires results of Cast Stone weathering and leaching studies. Studies needed to support IDF performance assessments. Benefits secondary waste Cast Stone and potential benefit to supplemental immobilization.

\subsection{Uncertainty Analysis and Methodology for PA}

Technology Needed: Parameter uncertainties and temporal degradation and the resulting effects on properties for the cementitious materials are often not taken into account or are over simplified although they can have significant impacts on predicted doses and risks for decision-making purposes. Improvements in both the characterization and modeling of these phenomenological properties for cementitious materials will provide more accurate predictions. A common source of debate regarding sensitivity and uncertainty analyses is the choice of deterministic and/or probabilistic approaches. For many years, in the low-level waste (LLW) disposal community, it was common to use deterministic approaches, which involved a base case and multiple sensitivity cases targeted at explaining or better illustrating the effects of changes in different parameters on the overall results of the assessment. Over time, there has been increased use of probabilistic approaches to replace or supplement the deterministic calculations. Properly addressing uncertainty is of critical importance to communicating human health risk assessment results in a transparent fashion for PAs and PA-like assessments. Work to address this technology need will be integrated with related ongoing work being conducted by the ASCEM program.

\section{Approach: Perform Probabilistic Calculations.}

To date, the IDF PA activities have relied on deterministic calculations. However, a variety of different scenarios and parameter sensitivity studies were conducted in a deterministic manner to address uncertainty analysis needs. The IDF PA involved the integration of results from several detailed experimental and modeling efforts including: waste form release, infiltration through a 
cover, vadose zone flow and transport, groundwater flow and transport, and dose. Base case analyses representing different waste management strategies (i.e., glass, bulk vitrification, and grout) were run and supplemented by numerous targeted sensitivity cases to illustrate the relative influence of changing assumptions on the performance of the system. Future PA activities should consider using probabilistic approaches.

Significances/Interfaces: Studies needed to support IDF performance assessments. There is only indirect benefit to low-temperature waste form work. Sensitivity analyses can guide waste form experimental work.

\subsection{Transformational Approaches for Waste Solidification}

Technology Needed: The NAS recognizes the voluminous technical literature on waste forms that have been developed over six decades of studies (NAS 2011). The NAS judged that there are opportunities to build upon this extensive knowledge base to provide new waste forms and/or new applications of waste forms to improve waste form performance and production efficiency. For example, new waste form materials designed for specific performance functions (e.g., high durability in specific disposal environments; compatibility with specific waste streams) or designed to remain stable over different ranges of time, depending on the half-life of the radionuclide could be developed. An important innovation has been to functionalize the surfaces of mesoporous materials with self-assembled organic monolayers that provide a substrate with high chemical selectivity, allowing these materials to be used in chemical separation processes. A further extension of this technology would be the development of mesoporous materials that are functionalized for the separation of specific radionuclides and suitable for the synthesis of waste forms. Advantages include high radionuclide loadings, high selectivity, and the possibility of a chemically durable final product.

A second example is that one of the most rapidly developing research areas in materials science is the use of computational simulation to determine fundamental physical and chemical properties of materials. In the 1980s, the use of pseudo-potentials to capture the behavior of chemically active electrons combined with density functional theory allowed the study of systems consisting of hundreds to thousands of atoms. At the same time, the rapid development of computer technology (faster processors and more efficient algorithms) led to the development of new tools for modeling the structure and properties of materials-and indeed, the new field of computational chemistry.

Approach: Encapsulating Binders for Granular Waste Forms.

Recently, granular materials have been considered as waste forms for LAW and WTP secondary liquid wastes (e.g., FBSR, goethite). To be considered for burial in the IDF these granular solids will require further encapsulation to meet transportation and non-dispersability requirements. Some of these materials may interfere with the setting and curing reactions or may not be stable in the chemical environment of the encapsulating binder slurry/paste. Development and evaluation of alternative binder materials for encapsulating these and future intermediate granular waste forms are needed to provide a robust complete system for stabilizing these waste forms.

Encapsulation studies have been performed on simulated Hanford LAW and WTP secondary wastes resulting from an engineering scale demonstration of FBSR (Crawford and Jantzen, 2011). Monoliths were produced from the non-radioactive FBSR products using ordinary Portland cement, high aluminum cements, ceramicrete, a variety of geopolymers and Nu-Cap binder. The 
monoliths were characterized and performed relatively well in leaching tests. Bench scale steam reformers have been used to produce non-radioactive and radioactive steam reforming products from Hanford LAW for characterization (Jantzen et al., 2013). Monoliths were fabricated from the non-radioactive and radioactive FBSR products using clay and fly ash. Both the fly ash and the clay based monoliths were found to perform well in long term leach testing.

Significances/Interfaces: A task focused on improving and optimizing a binder recipe for both FBSR and Fe(II)-treated goethite as alternative waste form for Tc. This activity is also germane to the final disposition of Tc should it be removed from the waste streams destined for vitrification and off-gas waste streams.

\subsection{Technetium Removal}

Technetium will not be removed from the aqueous LAW in the Hanford waste pretreatment facility, and will primarily end up immobilized in the LAW glass waste form. The LAW glass will be disposed in the IDF. Because ${ }^{99}$ Tc has a very long half-life and is highly mobile under subsurface conditions at the Hanford Site (Icenhower 2008, 2010), it has the potential to be a major dose contributor in the PA of the IDF. Substantial amounts of the ${ }^{99}$ Tc will be vaporized during vitrification of the waste, and will partition to the off-gas system where it will be recycled into the melter repeatedly to improve retention. Because pertechnetate is quite soluble in many subsurface environments as well as being volatile during vitrification and has been predicted to be the key risk driver in IDF PAs, effective management of ${ }^{99} \mathrm{Tc}$ is important to the overall success of the River Protection Project mission.

Removal of technetium during waste processing, followed by off-site disposal of technetium from the LAW, would eliminate a key risk contributor for the IDF PA for supplemental waste forms (Mann et al. 2003). Further, technetium removal has the potential to reduce overall treatment and disposal costs. Methods for removing ${ }^{99}$ Tc have been developed, and some have been deployed in specific applications. WRPS is developing some conceptual flow sheets for LAW treatment and disposal that could benefit from technetium removal. One of these flow sheets will specifically examine removing Tc from the LAW feed stream. This option and other potential options for Tc removal are shown in Figure 4-1. 
SRNL-STI-2013-00002

PNNL-22103

Revision 1

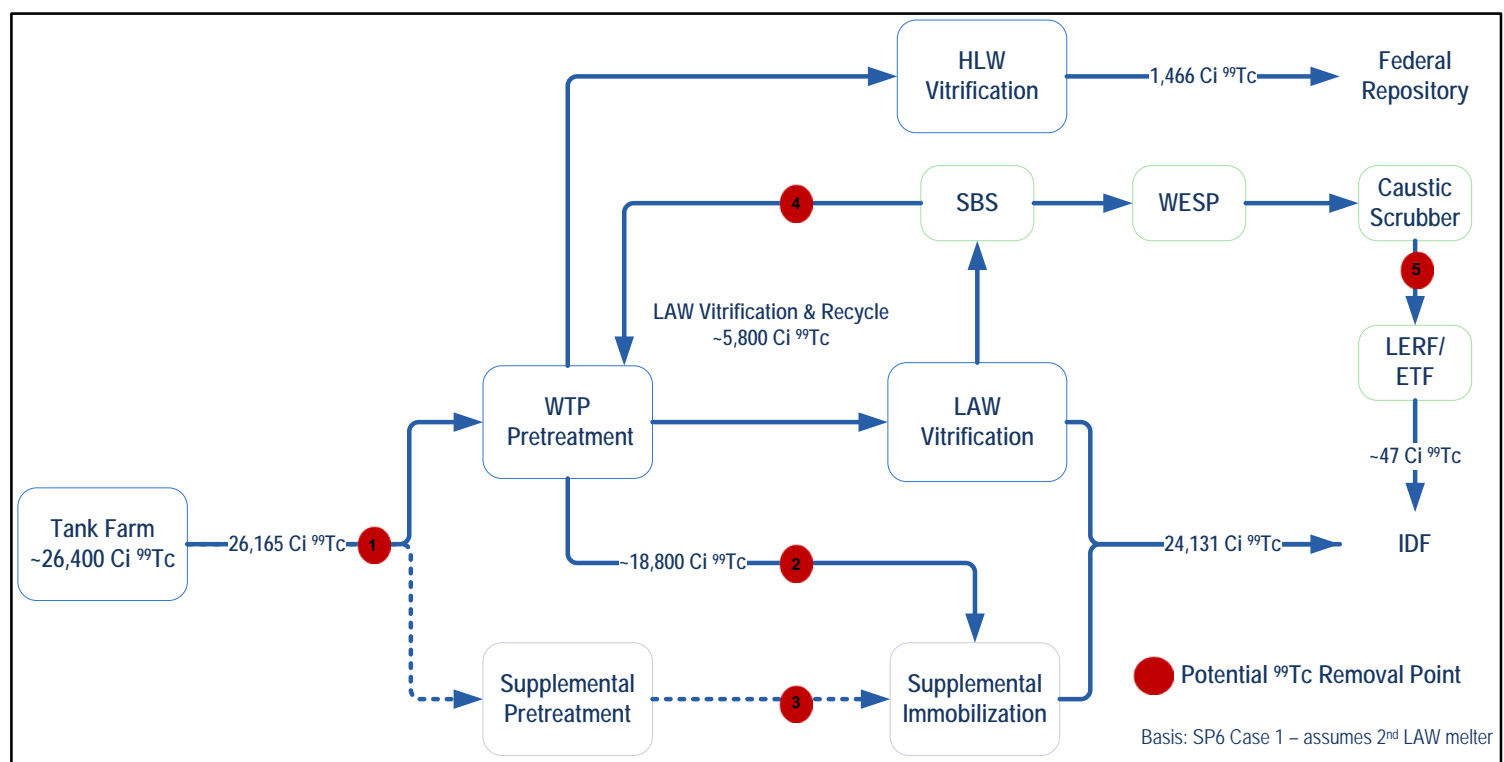

Figure 4-1. ${ }^{99}$ Tc Management Flow Sheet Overview

The Headquarters-sponsored Tc removal effort is focused on developing additional information concerning Tc removal technologies that could support DOE in making decisions on a number of areas including support for Direct Feed LAW, LAW Off-Gas Condensate recycle management, and supplemental pretreatment. Strategic tasks sponsored by ORP in 2013 examined treatment and disposition options for the LAW Off-Gas Condensate Recycle stream.

The science and technology needs associated with technetium removal were identified and grouped into the following broad categories:

- Removal of Tc from Off-Gas Condensate Streams

- Identification of Conditions for Non-Pertechnetate Species

- Development of Methods for Removing Non-Pertechnetate Species

- Development of an Alternative Tc Removal Elutable Resin

- Pretreatment of WTP LAW and the Temperature Effect on Resin Performance

- Alternative Waste Forms for Tc Eluate.

Summaries of the technology needs were prepared, and descriptions of potential technical solutions to addressing the needs were developed. Finally, a preliminary evaluation of the significances and interfaces was prepared for each activity to address the needs, based on augmenting and supporting ongoing Hanford Site activities.

\subsection{Removal of Tc from Off-Gas Streams}

Technology Needed: WRPS is currently supporting investigation of Tc removal from retrieved salt waste. Data is needed to evaluate the benefit in the removal of Tc from other waste streams. ORP supported preliminary investigations into treatment and disposal options for LAW Off-Gas Condensate Recycle. DOE-EM is supporting continuation of this work to provide a better projection of composition of this stream and further examine Tc removal. WRPS is supporting comprehensive treatment and disposal options for this stream, with a focus on Direct Feed LAW operation. 
SRNL-STI-2013-00002

PNNL-22103

Revision 1

Approach: Examine Removal of Tc from other Process Streams.

The WTP LAW Vitrification Facility will generate a substantial volume of secondary LAW in the off-gas treatment system. In particular, wastes generated in the LAW melter submerged bed scrubbers (SBS) and wet electrostatic precipitators (WESP) are expected to contain significant amounts of ${ }^{99} \mathrm{Tc}$, halides, and sulfates from the LAW melter feed stream. The Hanford tank waste operations simulator model predicts an estimated $37 \mathrm{Mgal}$ of SBS condensate will be generated in the WTP LAW Facility during its mission. These off-gas liquids are an attractive target for deploying a Tc removal process that could be used to support the Direct Feed LAW initiative. Testing would include:

- Initial development of separation and removal parameters

- Process selection

- Technology insertion optimization

- Screening of Tc and secondary waste disposal options.

In FY13 and early FY14, preliminary testing was performed on an initial simulant formulation, and results indicate that ${ }^{99} \mathrm{Tc}$ can be readily removed with reduction and sorption (Taylor-Pashow, et al., 2014). An arbitrary target decontamination factor of 100 was achieved using Sn(II) chloride with sorption of the ${ }^{99}$ Tc onto hydroxyapatite. Additional testing is needed to optimize the process and examine related chemicals and materials to enable selection of the most effective and compatible method. This testing would include developing the fundamental information needed to begin to select a viable flow-sheet for treatment and disposal. Tests also showed that other radionuclides expected to be present in the waste stream could also be removed by ion exchange or sorption. Additional R\&D is planned in FY14 assuming funding is appropriated.

Significances/Interfaces: Technologies are available that have high probabilities of success, but have not been tested. Although the volume of the recycle stream is modest, the impact on the system is significant because the concentrations of halides and sulfate can drive the LAW glass production schedule. A storage volume issue will be created if the WTP LAW facility begins operation prior to the completion of the WTP pretreatment facility. Breaking this stream into a separate disposal route could have substantial impact on the overall WTP mission.

\subsection{Identification of Conditions for Non-Pertechnetate Species}

Technology Needed: Technetium in Hanford tank wastes is known to exist in the form of the pertechnetate species $\left(\mathrm{TcO}_{4}{ }^{-}\right.$with an oxidation state of +7$)$ and also in other non-pertechnetate forms. In some tanks, this is typically $40-70 \%$ of the total Tc, and there is strong evidence that this is primarily a soluble non-pertechnetate form of technetium (Schroeder et al. 2001, 2002, 2004, McCabe et al. 2001), perhaps a Tc(I)carbonyl complexed with an organic ligand (Lukens et al. 2003, 2004, Shuh et al. 2003). The chemistry of the pertechnetate form is relatively well understood and methods have been developed for separating the pertechnetate from the tank wastes. Additional information is needed on the chemistry of the non-pertechnetate forms of technetium. Based on the precedent of literature syntheses, the current understanding of the formation of alkaline soluble non-pertechnetate involves the reduction of Tc(VII) by some agent with concomitant capture of carbon monoxide to form a $\left[\mathrm{Tc}(\mathrm{CO})_{3} \mathrm{~L}_{3}\right]^{+}$species, where $\mathrm{L}_{3}$ describes three oxygen donors, either from three, one oxygen-containing molecules (such as water) or from multiple oxygen atoms attached to the same molecule (e.g., gluconate). 
Details associated with the non-pertechnetate compound's structure, method of formation, and stability under potential processing conditions remain unknown. This work will address those issues. Specific technical questions include:

- What common organic molecules present in the Hanford tank supernatants are competent for coordination with Tc(I) carbonyl and so could be a source of the non-pertechnetate compound(s) in the Hanford tank supernatants? WRPS funding in FY13 identified the challenges in making stable coordinated or uncoordinated Tc(I) carbonyl compounds that were stable in alkaline solution. EM funded work in FY14 will examine the available data on Tc speciation in the tanks, assess needs to enable Tc speciation in actual waste, and examine redox stabilities of simulated non-pertechnetate species.

- Can the formation of soluble non-pertechnetate species use Tc(IV) dioxide as the Tc source?

- Can a direct non-pertechnetate sensor be developed? WRPS funding in FY13 enabled some progress in sensor development, which is continued in an EM-supported task.

- What are the rates of decomposition of $\left[\mathrm{Tc}(\mathrm{CO})_{3} \mathrm{~L}_{3}\right]^{+}$as a function of $\mathrm{L}$ and reaction conditions? FY13 work indicated that this type of species is unstable in alkaline solution, and further study and characterization under tank storage conditions is needed.

- Can alkaline-soluble reduced technetium simulants be formed using plant- and tank-typical chemicals and conditions?

- Can methods be developed to oxidize or remove non-pertechnetate species (EM funded in FY14).

This work will aid in developing methods for separating the non-pertechnetate forms from the wastes and will provide technical background for use in performance assessments for tank closure and disposal of waste forms containing non-pertechnetate species.

Recent attempts by PNNL to synthesize such species in alkaline solution have not been successful due to hydrolysis of the uncomplexed specie $\left[\mathrm{Tc}(\mathrm{CO})_{3}\left(\mathrm{H}_{2} \mathrm{O}\right)_{3}\right]^{+}$(Rapko, et al., 2013). This testing also showed that despite spectroscopic evidence that the actual tank waste species contains the $\left[\mathrm{Tc}(\mathrm{CO})_{3}\right]^{+}$moiety, it was observed to be unstable in laboratory tests, suggesting perhaps some regeneration or inter-conversion could be occurring. Fundamental studies of the hydrolytic behavior and speciation of the hydrolysis products $\left\{\left[\mathrm{Tc}(\mathrm{CO})_{3}(\mathrm{OH})_{\mathrm{n}}\left(\mathrm{H}_{2} \mathrm{O}\right)_{\mathrm{m}}\right]^{1-\mathrm{n}}\right\}$ were recommended to sort out the nature of the non-pertechnetate species in the tank waste.

The total inventory of non-pertechnetate in the tanks is not known, partially because there is not an easy method for analyzing it. Examination of available analysis data and correlation of the few measurements of non-pertechnetate with other species have been attempted (Rapko, et al., 2013b). The only trend observed was a negative correlation of non-pertechnetate concentration to total dose and ${ }^{137} \mathrm{Cs}$ concentrations. Development of a chemistry-based predictive approach was not achievable because of variability of the various analytes and the likely complexity of the chemistry related to formation of the non-pertechnetate species. There remains substantial uncertainty regarding the inventory and distribution of non-pertechnetate in the tanks. 
Quantifying non-pertechnetate in tank waste samples has typically been done by performing a pertechnetate-selective separation and measurement on the raw sample, in parallel with a "total technetium" measurement using a powerful oxidation technique followed by pertechnetate measurement. The difference between these methods is usually defined as the "nonpertechnetate" fraction. Developing a non-pertechnetate quantification method would simplify analysis and better quantify the amount of non-pertechnetate in the tank farms. Recent work has demonstrated a proof-of-principle that may one day lead to a spectroelectrochemical film device (Rapko, et al., 2013a) for selective speciation of non-pertechnetate.

Approach: Examine Chemistry and Stability of Tc(I) Carbonyl Complexes.

The first task will provide an enhanced set of fundamental binding data relevant to speciation of non-pertechnetate alkaline soluble Tc in Hanford tank waste. It is known that the Tc(I) tricarbonyl moiety can complex with various mono- and polydentate organic molecules (Alberto et al. 1998; Seifert et al. 2000). The Hanford tanks contain a variety of organic complexants and degradation products. This work will examine the relative stability of these tank-relevant organic fragments with the Tc(I) tricarbonyl moiety.

This task will measure the extent of ligand complexation to the starting Tc(I) carbonyl compounds. By obtaining the binding affinities of various organic molecules with the $\operatorname{Tc}(\mathrm{I})$ tricarbonyl moiety, insight as to the types of molecules likely to predominate in Hanford tank waste supernatants can be inferred. Such information will direct further stability and decomposition studies such that any simulant reactivity studies are made most relevant to the behavior in actual Hanford tank waste supernatants.

The second task will examine the rate and extent of conversions of $\mathrm{TcO}_{2}$ to $\mathrm{Tc}(\mathrm{I})$-tricarbonyl $\left[(\mathrm{CO})_{3} \mathrm{Tc}\left(\mathrm{H}_{2} \mathrm{O}\right)_{3}{ }^{+}\right]$. This study will be performed both in the presence and absence of an external radiation source. The goal is to determine whether a Tc(IV) pathway to Tc(I) carbonyl compounds is viable in alkaline solution. This information will provide guidance for what conditions could lead to additional non-pertechnetate Tc formation during retrieval and processing.

The third task will develop a non-pertechnetate Tc sensor. It has been shown (SA Bryan unpublished results) for both Re and Tc that complexation of $\left[\mathrm{Tc}(\mathrm{CO})_{3} \mathrm{~L}_{3}\right]^{+}$and $\left[\operatorname{Re}(\mathrm{CO})_{3} \mathrm{~L}_{3}\right]^{+}$ with poly-aromatic organic compounds readily yields materials with unique fluorescent spectroscopic signatures. Such signatures can be detected even at very low (nanomolar or less) concentrations of metal. This task seeks to apply this chemistry to develop a more readily applicable method for direct detection of non-pertechnetate species in Hanford tank waste supernatants. A proof of principle for a method suitable to rapidly quantify non-pertechnetate in Hanford tank supernatants will be established. Such a method will provide the ability to evaluate the non-pertechnetate Hanford site inventory more quickly and cheaply than can any current technology.

The fourth task will examine tank-friendly methods for removal or conversion of nonpertechnetate to pertechnetate. It is known that, under certain aerobic conditions, the fraction of non-pertechnetate Tc in Hanford tank wastes slowly decreases over time (Schroeder et al. 2001). However, the conditions necessary to facilitate this re-oxidation remain unclear. This task seeks to develop a range of other methods to remove or convert the non-pertechnetate species to pertechnetate. The focus of this work will be on simple technology that can be readily deployed, and that may have co-benefits for removal of soluble strontium and actinides from those tanks needing that treatment. 
The fifth task is to explore the creation of alkaline-soluble reduced technetium using plant- and tank-typical chemicals and conditions. Creation of reduced technetium from aqueous solution has been reported (Meyer et al. 1985) and those methods would be used with the simulants to attempt to create soluble reduced technetium. It is anticipated that the complexant simulants will dissolve reduced technetium, given their strong success in dissolving transition and rare earth metal ions in alkaline solutions to much higher levels than would be seen without complexation. This will create a comprehensive simulant for future use. Connection of soluble nonpertechnetate species with typical Hanford waste chemistry and process conditions should produce species of interest, and most likely to be similar to what further waste processing will encounter. This task will also consider the fact that there may be a small amount ( 2-4\%) of a non-pertechnetate species at mass-99 that may not be technetium, in both Hanford and SRS waste (King et al. 2000). It is suspected that this mass-99 species is Ru-99. It is important to identify this species and formulate an analytical procedure to quantify it because of its potential impact on the Performance Assessments. If Tc removal is selected at Hanford, it will otherwise be challenging to certify that Tc is being completely removed.

In total, the five activities described above will address each of the key questions mentioned in the technology needs section of Section 4.2.

Significances/Interfaces: These five subtasks will provide mechanistic and needed understanding of the nature of the non-pertechnetate species and their stability, which will augment empirical Cast Stone leaching and solid phase characterization studies described in Section 3.2 and Section 3.6, respectively. Among the five subtasks, the relative rating would be Tc-carbonyl to tank anions binding $>\mathrm{TcO}_{2}$ to $\mathrm{Tc}(\mathrm{I})$ carbonyl $>$ n-pertechnetate to pertechnetate conversion in alkaline solution $\sim$ creating a simulant capable of generating soluble reduced Tc from pertechnetate $>$ soluble n-pertechnetate sensor development.

\subsection{Development of an Alternative Tc Removal Elutable Resin}

Technology Needed: Currently, WRPS is investigating the removal of Tc from retrieved salt streams using an IBC Technologies-patented elutable ion exchange resin-SuperLig 639. This resin is solely provided by IBC. Therefore, a risk exists that DOE will develop the pretreatment process and IBC will no longer makes or chooses to sell the resin in the future.

\section{Approach: Testing of Alternative Resins for Tc Removal.}

Implementing technetium removal in support of supplemental immobilization requires the maturation (technology readiness level [TRL] 6) of an elutable ion-exchange media capable of removing greater than $99 \%$ of the pertechnetate form of ${ }^{99}$ Tc. SuperLig 639, a water elutable ionexchange resin, was chosen as the primary technology. In an effort to limit reliance on this sole removal technology, it is imperative to develop an alternative Tc removal resin to at least a TRL of 4. This will require selection of an alternative resin, or resins, such as ABEC-2000, assessment of current manufacturing options and failure points, determination of the resin's physical properties and characteristics, performing preliminary chemical stability and isotherm studies, and finally, conducting column tests using simulants. The objective of these efforts will be to get at least one alternative approach sufficiently developed that it could be quickly deployed should the primary technology fail to meet waste processing requirements. 
Significances/Interfaces: Relying on a single supplier for the most important component in the process carries risk. This activity is a high priority because of the risks identified and the potential for cost savings if a Tc removal process is implemented.

\subsection{Pretreatment of WTP LAW and the Temperature Effect on Resin Performance}

Technology Needed: Insufficient information is available to support the pretreatment of cesiumdecontaminated LAW coming from the WTP for Tc removal using the proposed WRPS flow sheet.

\section{Approach: Examine the Effect of Elevated Temperature on Tc Removal Operations.}

Currently, WRPS is examining the coupled operation of Tc ion exchange with cesium pretreatment in a Tank Farm-based operation or at the WTP. The historical work on the Tc ion exchange was performed assuming ambient temperature of the LAW. To improve aluminum solubility and decrease the demand for caustic in WTP, the cesium ion exchange flow sheet has recently been altered by increasing the Cs ion exchange column operating temperature to $45{ }^{\circ} \mathrm{C}$. If technetium removal from LAW treated in WTP is to be considered, the effect of the elevated temperature on the Tc removal by ion exchange will need to be determined. The purpose of this work would be focused on developing Tc isotherms, column ion exchange behavior, and resin stability at elevated temperatures up to $50{ }^{\circ} \mathrm{C}$. Other variables to include in this testing are increased range of sodium concentrations and chemical compositions, optimized flow rates, and spent resin disposal. This task will also involve developing a user-friendly version of the Tc ion exchange computer model for broader use.

Testing and computer modeling have been completed on simulant of the overall tank waste composition based on the HTWOS projection of feed to Supplemental LAW (Nash, et al., 2013). Results indicate that operating the columns at $45{ }^{\circ} \mathrm{C}$ will cause a $~ 50 \%$ decrease in the quantity of waste processed per loading cycle. The decrease would make operation of the process more challenging because of the shorter loading cycle and doubling of eluate volume, but appears to be a viable process to remove $99 \%$ of the pertechnetate from LAW.

Significances/Interfaces: Elevated temperature conditions have been tested in columns with Re. Column testing with Tc has not been done at elevated temperature, but has been modeled using the correlations developed with Re. However, resin stability at elevated temperature has not been evaluated. If treatment of WTP-decontaminated LAW is to be considered, these data are vital to avoid cooling and diluting the waste stream. Similarly, testing has not been performed on the WTP-decontaminated LAW composition, which is a high density fluid at $\sim 8 \mathrm{M}\left[\mathrm{Na}^{+}\right]$, which will cause the resin to float, cause poor bed packing, and thereby disrupt column breakthrough profiles. Testing is needed to examine column and flow conditions that would minimize column profile issues and achieve a good decontamination of Tc in this high density solution.

\subsection{Alternative Waste Forms for Tc Eluate}

Technology Needed: There is insufficient information to support the selection of a preferred method of disposing the Tc eluate from any Tc removal activity within the WRPS-sponsored $\mathrm{R} \& \mathrm{D}$ program. If $\mathrm{Tc}$ is removed using an elutable ion exchange resin, the process will produce a Tc concentrate eluate stream that will require disposal. Currently, HLW vitrification is the assumed disposal path, but technically, alternative treatment options exist, including off-site disposal as a stabilized (solid) waste form. Both of these options have advantages and disadvantages. 
SRNL-STI-2013-00002

PNNL-22103

Revision 1

\section{Approach: Immobilize Tc in a Metallic Waste Form or Other Stabilized Waste Form}

The Fuel Cycle R\&D program operated by the Office of Nuclear Energy (NE) is taking a different approach to the Tc removed from used fuel processing. In the NE process, once the Tc is removed from the uranium product, a reasonable solution for Tc immobilization is to incorporate elemental Tc into a corrosion-resistant metallic waste form. Currently, Fe-Mo metallic waste forms are being considered for the retention and ultimate long-term disposal of Tc from used nuclear fuel recycle. The proof of principle activity will examine the use of metallic forms for disposal of the Tc eluate from Hanford processing.

Approach: Develop Goethite Mineral Form for Sequestering Tc

Synthesized goethite, $\alpha-\mathrm{FeOOH}$, was successfully used with the addition of aqueous $\mathrm{Fe}(\mathrm{II})$ to sequester Tc present in both deionized water and waste solutions simulated to represent tank waste solutions derived from low-activity-waste glass melter off-gas scrubbers used at the WTP (Josephson and Westsik, 2011). The total amount of Tc present in the final goethite solid showed a high degree of Tc sequestration, $90 \%$ to $100 \%$. Successful incorporation of Tc(IV) within the goethite mineral lattice and subsequent goethite armoring limited re-oxidation of Tc(IV) and its subsequent release from the Tc-goethite waste form, even when the final product was placed in oxidizing environments that typify shallow waste burial facilities. The more stabilized and strongly coordinated Tc(IV) within the goethite lattice in the Tc-sequestered goethite, especially after additional goethite was precipitated as an armoring layer, provides significant advantages for slowing the release of Tc disposed of in nuclear waste repositories. Work is now needed to optimize the goethite precipitation process for Tc removal, scale up, and develop an immobilization method for the goethite particles.

\section{Approach: Enhance Tc Retention in Grouts and Other Absorbents.}

Testing has not been performed to evaluate generation of alternative solid forms, such as grouts or absorbents. Grout formulations will be developed and examined for leach behavior to enable selection of a potential disposal path. Similarly, absorbents exist that will be tested for permanent or interim sequestration of Tc, such as Sn(II) apatite. This material will be evaluated to determine if it can be applied to further concentrate the Tc from the ion exchange eluate, to minimize the disposal volume. This could also be evaluated to determine if the Sn(II) apatite matrix could be used for interim safe storage of Tc (as opposed to a soluble aqueous eluate stream), and eventually incorporated into HLW glass.

Significances/Interfaces: Disposition of the removed Tc will be a key parameter in producing a viable Tc management strategy. If the Tc-removal process can be decoupled from the HLW mission, this avoids a potential incompatibility in schedules and mitigates interim storage of the Tc stream.

\subsection{Summary}

PNNL and SRNL examined the technical risks and uncertainties associated with the LAW and secondary waste Cast Stone waste immobilization projects at Hanford. Science and technology needs were identified for work associated with 1) conducting performance assessments and risk assessments of waste form and disposal system performance, and 2) technetium chemistry in tank wastes and separations of technetium from waste processing streams. Technical approaches to 
SRNL-STI-2013-00002

PNNL-22103

Revision 1

addressing the science and technology needs were identified and prioritized. The following table summarizes the needs, approaches to address those needs, and sequencing priorities for the first years of a science and technology program to address low-temperature waste forms and technetium separations as an enabling technology. 
SRNL-STI-2013-00002

PNNL-22103

Revision 1

Table 5-1. Summary of Technology Needs, Approaches, and Sequencing Priorities

\begin{tabular}{|c|c|c|}
\hline & & Sequencing \\
\hline 3.0 & Assessing Long-Term Waste Form Performance & \\
\hline \multirow[t]{2}{*}{3.1} & Hydraulic Properties & \\
\hline & $\begin{array}{l}\text { Investigate the efficacy/practicality of new NMR tomographic and } x \text { - } \\
\text { ray/neutron spectroscopic methods on Cast Stone specimens }\end{array}$ & Long Term \\
\hline \multirow[t]{2}{*}{3.2} & Effective Diffusion Coefficients & \\
\hline & $\begin{array}{l}\text { Extend Effective Diffusivity Measurements in Support of the LAW } \\
\text { Supplemental Immobilization Testing Program and Expanded Secondary } \\
\text { Waste Immobilization Tests }\end{array}$ & Near term \\
\hline \multirow[t]{2}{*}{3.3} & Solubility and $K_{d}$ & \\
\hline & Perform Additional Adsorption-Desorption Tests Using Cast Stone Leachates & Near term \\
\hline \multirow[t]{2}{*}{3.4} & Cast Stone Formulation and Impact on Properties & \\
\hline & $\begin{array}{l}\text { Expand Existing LAW Supplemental Immobilization Cast Stone Testing } \\
\text { Program to Include Broader Waste Chemistries }\end{array}$ & Near Term \\
\hline \multirow[t]{2}{*}{3.5} & Impact of Curing Conditions and Scale on Cast Stone Properties & \\
\hline & Curing Impacts with Focus on Microstructure and Controlling Porosity & Near Term \\
\hline \multirow[t]{4}{*}{3.6} & Expected Fracturing in Cast Stone with Time & \\
\hline & Effect of Carbonation Reactions & Near Term \\
\hline & Effect of Sulfate Attack and Ettringite Formation & Near Term \\
\hline & Effect of Aging & Mid Term \\
\hline \multirow[t]{4}{*}{3.7} & Technetium Speciation and Impacts of Redox Changes & \\
\hline & Cast Stone Technetium Speciation Characterization & Near Term \\
\hline & Characterization of the Technetium Oxidation Front for Cast Stone & Near Term \\
\hline & Leaching of Non-Pertechnetate Technetium from Cast Stone & Mid Term \\
\hline \multirow[t]{6}{*}{3.8} & Cast Stone Long Term Weathering & \\
\hline & Accelerated Test Method Investigations & Mid Term \\
\hline & Porosity Changes with Weathering & \\
\hline & Examining Lysimeter Behavior for Tc in Cast Stone Samples & Mid Term \\
\hline & Development of a Test Method to Demonstrate Equivalent Durability & Long Term \\
\hline & Literature Review on Natural Analogs and Ancient Cements & Near Term \\
\hline \multirow[t]{2}{*}{3.9} & Multi-Component Interactions & \\
\hline & Waste Package Release Testing & Mid Term \\
\hline \multirow[t]{2}{*}{3.10} & Cast Stone Contaminant Release Model---Conceptual and Numerical & \\
\hline & $\begin{array}{l}\text { Choose/improve Existing Mechanistic Based Cementitious Waste Form } \\
\text { Release Conceptual and Numerical Codes }\end{array}$ & Long Term \\
\hline \multirow[t]{2}{*}{3.11} & Uncertainty Analysis and Methodology for PAs & \\
\hline & Perform Probabilistic Calculations & Long Term \\
\hline \multirow[t]{2}{*}{3.12} & Transformational Approaches for Waste Solidification & \\
\hline & Encapsulating Binders for Granular Waste Forms & Mid Term \\
\hline
\end{tabular}


SRNL-STI-2013-00002

PNNL-22103

Revision 1

Table 5-1. (contd)

\begin{tabular}{|c|c|c|}
\hline & & Sequencing \\
\hline 4.0 & Technetium Removal & \\
\hline \multirow[t]{2}{*}{4.1} & Removal of Tc from Off-Gas Streams & \\
\hline & Examine Removal of Tc from other Process Streams & Near Term \\
\hline \multirow[t]{6}{*}{4.2} & Identification of Conditions for Non-Pertechnetate Species & \\
\hline & $\begin{array}{l}\text { Binding constants of key tank constituents to }(\mathrm{CO})_{3} \mathrm{Tc}\left(\mathrm{H}_{2} \mathrm{O}\right)_{3}{ }^{+} \text {and } \\
(\mathrm{CO})_{3} \mathrm{Tc}(\mathrm{OH})\left(\mathrm{H}_{2} \mathrm{O}\right)_{2}\end{array}$ & Near Term \\
\hline & Conversion of $\mathrm{TcO}_{2}$ to $(\mathrm{CO})_{3} \mathrm{Tc}_{\mathrm{C}}\left(\mathrm{H}_{2} \mathrm{O}\right)_{3}{ }^{+}$ & Near Term \\
\hline & Non-pertechnetate sensor development & Mid Term \\
\hline & Non-pertechnetate removal or conversion to pertechnetate & Near Term \\
\hline & $\begin{array}{l}\text { Create Soluble Non-Pertechnetate Chemistry using Plant- and Tank-Typical } \\
\text { Conditions }\end{array}$ & Near Term \\
\hline \multirow[t]{2}{*}{4.3} & Development of an Alternative Tc Removal Elutable Resin & \\
\hline & Testing of Alternative Resins for Tc Removal & Near Term \\
\hline \multirow[t]{2}{*}{4.4} & Pretreatment of WTP LAW and the Temperature Effect on Resin Performance & \\
\hline & Examine the Effect of Elevated Temperature on Tc Removal Operations & Near Term \\
\hline \multirow[t]{4}{*}{4.5} & Alternative Waste Forms for Tc Eluate & \\
\hline & Immobilize Tc in a metallic waste form or other stabilized waste form & Near Term \\
\hline & Develop Goethite Mineral Form for Sequestering Tc & Near Term \\
\hline & Enhance Tc retention in grouts and other absorbents & Near Term \\
\hline
\end{tabular}

\subsection{References}

Alberto R, R Schibli, A Egli, AP Schubiger, U Abram, and TA Kaden. 1998. "A Novel Organometallic Aqua Complex of Technetium for the Labeling of Biomolecules: Synthesis of $\left[{ }^{99 \mathrm{~m}} \mathrm{Tc}\left(\mathrm{OH}_{2}\right)_{3}(\mathrm{CO})_{3}\right]^{+}$from $\left[{ }^{99 \mathrm{~m}} \mathrm{TcO}_{4}\right]^{-}$in Aqueous Solution and Its Reaction with a Bifunctional Ligand.” Journal of the American Chemical Society 120:7987-7988.

Almond, P M, DI Kaplan, CA Langton, DB Stefanko, WA Spencer, A Hatfield, and Y Arai. 2012. Method Evaluation and Field Sample Measurements for the Rate of Movement of the Oxidation Front in Saltstone. SRNL-STI-2012-00468, Revision 0, Savannah River National Laboratory, Aiken, South Carolina.

Aloy AS, JR Harbour, EW Holtzscheiter, and CA Langton. 2008. "Evaluation of Durability of Mortars and Concretes Used in Ancient Structures.” In Materials Research Society Symposium Proceedings, Vol. 1107, Paper \#127, Materials Research Society, Pittsburgh, Pennsylvania.

Bacon DH, BP McGrail, VL Freedman, G Ventura, P Risoluti, and KM Krupka. 2002. "Performance Assessment of Low-Level Waste Disposal Facilities Using Coupled Unsaturated Flow and Reactive Transport Simulators.” Materials Research Society Symposium Proceedings 71(3):267-274.

Bredt P, AR Felmy, PA Gauglitz, D Hobbs, S Krahn, N Machara, M McIlwain, BA Moyer, AP Poloski, K Subramanian, JD Vienna, and B Wilmarth. 2008. Scientific Opportunities to Reduce Risk in Nuclear Process Science. PNNL-17699, Pacific Northwest National Laboratory, Richland, Washington. 
SRNL-STI-2013-00002

PNNL-22103

Revision 1

Brown CF, WR Wilmarth, RJ Serne, KM Fox, JH Westsik, Jr, DJ Mccabe, BM Rapko, CA Nash, and A Cozzi. 2013. Assessment of the Cast Stone Low-Temperature Waste Form Technology Coupled with Technetium Removal - 14379. In WASTE MANAGEMENT SYMPOSIA 2014. PNNL-SA-99494, Pacific Northwest National Laboratory, Richland, Washington.

Buck JW, BP McGrail, DH Bacon, VL Freedman, P Ciabotti, and BL Hoopes. 2002. Modeling Methodology for Preliminary Performance Assessment of Italian Low-Level Radioactive Waste Repository. PNWD-3176, Battelle Pacific Northwest Division, Richland, Washington.

Cadelli N, G Cottone, S Orlowski, G Bertozzi, F Girardi, and A Saltelli. 1988. Performance Assessment of Geological Isolation Systems for Radioactive Waste (PAGIS). Summary. EUR 11775 EN, Commission of the European Communities, Luxembourg.

CBP - Cementitious Barriers Partnership. 2009a. Overview of the U.S. Department of Energy and Nuclear Regulatory Commission Performance Assessment Approaches. CBP-TR-2009-001, http://cementbarriers.org/reports/.

CBP - Cementitious Barriers Partnership. 2009b. Review of Mechanistic Understanding and Uncertainty Analysis Methods for Predicting Cementitious Barrier Performance. CBP-TR2009-002, http://cementbarriers.org/reports/.

Cozzi AD and MD Fowley. 2013. Task Technical and Quality Assurance Plan for the Cast Stone Engineering Scale Demonstration. SRNL-RP-2013-00512, Revision 0, Savannah River National Laboratory, Aiken, South Carolina.

Crawford CL and CM Jantzen. 2011. Evaluation of THOR ${ }^{\mathrm{TM}}$ Mineralized Waste Forms (Granular and Monolith) for the DOE Advanced Remediation Technologies (ART) Phase 2 Project. SRNL-STI-2009-00505, Revision 0, Savannah River National Laboratory, Aiken, South Carolina.

Denham ME and MR Millings. 2012. Evolution of Chemical Conditions and Estimated Solubility Controls on Radionuclides in the Residual Waste Layer During Post-Closure Aging of High-Level Waste Tanks. SRNL-STI-2012-00404, Savannah River National Laboratory, Aiken, South Carolina.

DOE 2012. DOE (U.S. Department of Energy). 2012. Final Tank Closure and Waste Management Environmental Impact Statement for the Hanford Site,Richland, Washington (TC \& WM EIS) DOE/EIS-0391. Office of River Protection, U.S. Department of Energy, Richland, WA. http://www.hanford.gov/page.cfm/FinalTCWMEIS

DOE-EM - U.S. Department of Energy Office of Environmental Management. 2008. U.S. Department of Energy Office of Environmental Management Engineering \& Technology Roadmap. Washington, D.C.

Flach GP, JM Jordan, and T Whiteside. 2009. Numerical Flow and Transport Simulations Supporting the Saltstone Disposal Facility Performance Assessment. SRNL-STI-2009-00115, Savannah River National Laboratory, Aiken, South Carolina. 
SRNL-STI-2013-00002

PNNL-22103

Revision 1

Fox KM, KA Roberts, and TB Edwards. 2014. Cast Stone Formulation at Higher Sodium Concentrations. SRNL-STI-2013-00499, Rev. 2, Savannah River National Laboratory, Aiken, South Carolina.

Fox KM, 2014. Meeting Minutes: Tank Waste Integration Workshop - Cementitious Waste Forms. SRNL-OS-2014-00029, Savannah River National Laboratory, Aiken, South Carolina.

IAEA - International Atomic Energy Agency. 1989. Natural Analogues in Performance Assessments for the Disposal of Long Lived Radioactive Wastes. Technical Reports Series No. 304, Vienna, Austria.

Icenhower JP, N Qafoku, JM Zachara, and WJ Martin. 2010. "The Biogeochemistry of Technetium: A Review of the Behavior of an Artificial Element in the Natural Environment.” American Journal of Science 310(8):721-752. doi:10.2475/08.2010.02.

Icenhower JP, N Qafoku, WJ Martin, and JM Zachara. 2008. The Geochemistry of Technetium: A Summary of the Behavior of an Artificial Element in the Natural Environment. PNNL-18139, Pacific Northwest National Laboratory, Richland, Washington.

Josephson, GB and JH Westsik, Jr. 2011. Goethite Bench-Scale and Large-Scale Preparation Tests. PNNL-20860, Pacific Northwest National Laboratory, Richland, Washington.

King, WD, Hassan, NM, McCabe, DJ, Walker, DD, 2000. Intermediate-Scale Ion Exchange Removal of Cesium and Technetium from Savannah River Site Tank 44 F Supernate Solution, BNF-003-98-0230 R/0, July 3, 2000b

Kohn, J. L., K. L. Dixon, and R. L. Nichols. 2011. Fractured Media Update. SRNL-L3200-201200029, Rev. 0, Savannah River National Laboratory, Aiken, South Carolina.

Korb JP. 2009. "NMR and Nuclear Spin Relaxation of Cement and Concrete Materials." Current Opinion in Colloid \& Interface Science 14:192-202.

Krupka KM and RJ Serne. 1998. Performance Assessment of Low-Level Radioactive Waste Disposal Facilities: Effects on Radionuclide Concentrations by Cement/Ground-Water Interactions. NUREG/CR-6377, U. S. Nuclear Regulatory Commission, Washington, D. C.

Langton CA. 1980. Longevity of Borehole and Shaft Sealing Materials: 2, Characterization of Cement-Based Ancient Building Material. ONWI-202, Office on Nuclear Waste Isolation, Battelle Memorial Institute, Columbus, Ohio.

Langton CA. 2012. Transport Through Cracked Concrete: Literature Review. SRNL-STI-201200267 Rev. 0, Savannah River National Laboratory, Aiken, South Carolina.

Langton, CA and PM Almond. 2013. Cast Stone Oxidation Front Evaluation: Preliminary Results for Samples Exposed to Moist Air. SRNL-STI-2013-00541, Revision 0, Savannah River National Laboratory, Aiken, South Carolina. 
SRNL-STI-2013-00002

PNNL-22103

Revision 1

Langton, C\A, DB Stefanko, and HH Burns, 2012. Saltstone Oxidation Study: Leaching Method. SRNL-STI-2012-00728, Savannah River National Laboratory, Savannah River Site, Aiken, South Carolina and WM Symp, Feb. 24 to 28, 2013, Phoenix, Arizona

Linklater CM, Y Albinsson, WR Alexander, I Casas, IG McKinley, and P Sellin. 1996. “A Natural Analogue of High-pH Cement Pore Waters from the Maqarin Area of Northern Jordan: Comparison of Predicted and Observed Trace-Element Chemistry of Uranium and Selenium.” Journal of Contaminant Hydrology 21:59-69.

Lukens, WW, Shuh, DK, Schroeder, NC, Ashley, KR. 2003. Investigations to Identify the Soluble, Non-pertechnetate Species in the High-Level Nuclear Waste at the Hanford Site, LBNL56315.

Lukens WW, DK Shuh, NC Schroeder, and KR Ashley. 2004. "Identification of the NonPertechnetate Species in Hanford Waste Tanks, Tc(I)-Carbonyl Complexes.” Environmental Science \& Technology 38:229-233.

Lukens WW, DK Shuh, NC Schroeder, and KR Ashley. 2006. "Behavior of Technetium in Alkaline Solution: Identification of Non-Pertechnetate Species in High-Level Nuclear Waste Tanks at the Hanford Reservation.” ACS Symposium 943:302-317.

Mann FM, G Parsons, PE LaMont, SH Finfrock, R Khaleel, RJ Puigh, PD Rittmann, DH Bacon, and BP McGrail. 2005. Hanford Integrated Disposal Facility Performance Assessment: 2005 Version Rev. 0, ORP-25439, U.S. Department of Energy Office of River Protection, Richland, Washington.

Mann FM, RJ Puigh, R Khaleel, S Finfrock, BP McGrail, DH Bacon, and RJ Serne. 2003. Risk Assessment Supporting the Decision on the Initial Selection of Supplemental ILAW Technologies. RPP-17675, Rev. 0, CH2M HILL Hanford Group, Inc., Richland, Washington.

McCabe DJ, NM Hassan, WD King, JL Steimke, MA Norato, LL Hamm, LN Oji, and ME Johnson. 2001. Comprehensive Scale Testing of the Ion Exchange Removal of Cesium and Technetium from Hanford Tank Wastes. WSRC-MS-2000-00499, Westinghouse Savannah River Company, Aiken, South Carolina.

McDonald PJ, J Mitchell, M Mulheron, PS Aptaker,J-P Korb, and L Monteilhet. 2007. "TwoDimensional Correlation Relaxometry Studies of Cement Pastes Performed Using a New OneSided NMR Magnet.” Cement and Concrete Research 37:303-309.

McGrail B, D Bacon, R Serne, and E Pierce. 2003. A Strategy to Assess Performance of Selected Low-Activity Waste Forms in an Integrated Disposal Facility. PNNL-14362, Pacific Northwest National Laboratory, Richland, Washington.

Meyer, RE, Arnold, WD., and Case, FI. 1985. "Valence Effects on Solubility and Sorption The Solubility of Tc Oxides, ORNL-6199 (NUREG/CR-4309).

NAS - National Academy of Sciences. 2009. Advice on the Department of Energy's Cleanup Technology Roadmap - Gaps and Bridges. Washington, D.C. 
SRNL-STI-2013-00002

PNNL-22103

Revision 1

NAS - National Academy of Sciences. 2010. Science and Technology for DOE Site Cleanup Workshop Summary. Washington, D.C.

NAS - National Academy of Sciences. 2011. Waste Forms Technology and Performance Final Report. Washington, D.C.

Nash, CA, MM Morse,DJ McCabe, LL Hamm, and FG Smith. 2013.Ion Exchange Column Tests Supporting Technetium Removal Resin Maturation, SRNL-STI-2013-573, Rev. 1, Savannah River National Laboratory, Aiken, South Carolina.

NRC - U.S. Nuclear Regulatory Commission. 2012. Technical Evaluation Report for the Revised Performance Assessment for the Saltstone Disposal Facility at the Savannah River Site, South Carolina. Washington, D.C.

Pabalan RT, FP Glasser, DA Picket, GR Walter, S Biswas, MR Juckett, LM Sabido, and JL Myers. 2009. Review of Literature and Assessment of Factors Relevant to Performance of Grouted Systems of Radioactive Waste Disposal. CNWRA 2009-001, Center for Nuclear Waste Regulatory Analyses, San Antonio, Texas.

http://adamswebsearch2.nrc.gov/webSearch2/main.jsp?AccessionNumber='ML090980426'

Papathanassiu AE, W Gong, H Xu, D McKeown, and IL Pegg. 2013. Oxidation Rate Measurement and Humidity Effects on Saltstone. VSL-13R3010-1, Vitreous State Laboratory, The Catholic University of America, Washington, DC.

Pierce EM, BP McGrail, EA Rodriguez, HT Schaef, KP Saripalli, RJ Serne, KM Krupka, PF Martin, SR Baum, KN Geiszler, LR Reed, and WJ Shaw. 2004. Waste Form Release Data Package for the 2005 Integrated Disposal Facility Performance Assessment. PNNL-14805, Pacific Northwest National Laboratory, Richland, Washington.

Rapko, BM, SA Bryan, S Chatterjee, MK Edwards, TG Levitskaia, JM Peterson, RA Peterson, SI Sinkov. 2013a. Investigations into the Nature of Alkaline Soluble, Non-Pertechnetate Technetium, PNNL-22957, Pacific Northwest National Laboratory, Richland, Washington.

Rapko, BM, SA Bryan, JL Bryant, S Chatterjee, MK Edwards, JY Houchin, T Janik, TG Levitskaia, JM Peterson, RA Peterson, SI Sinkov, FN Smith, and R Wittman. 2013b. Development of a Chemistry-Based, Predictive Method for Determining the Amount of NonPertechnetate Technetium in the Hanford Tanks: FY2012 Progress Report, PNNL-22173, Pacific Northwest National Laboratory, Richland, Washington.

Reigel, MM, BR Pickenheim, and WE Daniel. 2012. Process Formulations and Curing Conditions that Affect Saltstone Properties. SRNL-STI-2012-00558, Revision 0, Savannah River National Laboratory, Aiken, South Carolina.

Roy DM and CA Langton. 1989. Studies of Ancient Concrete as Analogs of Cementitious Sealing Materials for a Repository in Tuff. LA-11527-MS, Las Alamos, New Mexico.

Rustick J, J Clarke and M Letourneau 2011. Building Confidence in Performance Assessments 11394. in WM'2011, WMSymposia, Phoenix, Arizona.

http://www.wmsym.org/archives/2011/papers/11394.pdf 
SRNL-STI-2013-00002

PNNL-22103

Revision 1

Sarkar S, S Mahadevan, JCL Meeussen, HA van der Sloot, KG Brown, KG \& DS Kosson. 2010. Probabilistic Durability Analysis Of Cementitious Materials Under Combined Sulfate Attack And Calcium Leaching - 10149. in WM'2010, WMSymposia, Phoenix, Arizona. http://www.wmsym.org/archives/2010/pdfs/10149.pdf

Sarkar, S, Mahadevan, D. Kosson, E Samson, JCL Meeussen, H van der Sloot, and G Flach. 2011. Technical Insights for Saltstone PA Maintenance. CBP-RP-2010-013-01, rev. 0 http://cementbarriers.org/reports/

Schroeder NC, SD Radzinski, KR Ashley, AP Truong, and GD Whitener. 2001. "Feed adjustment chemistry for Hanford 101-SY and 103-SY tank waste: Attempts to oxidize the nonpertechnetate species.” Journal of Radioanalytical and Nuclear Chemistry 250:271-284.

Schroeder, NC, Olivares, JA, Ashley, KR. 2002 Identification of Non-Pertechnetate Species in Hanford Tank Waste, Their Synthesis, Characterization, and Fundamentals Chemistry. DOE Report 81988.

Schroeder, NC, Olivares, JA, Ashley, KR. 2004. Identification of Non-Pertechnetate Species in Hanford Tank Waste, Their Synthesis, Characterization, and Fundamentals Chemistry, LA-UR04-4277.

Seifert S, J-U Kunstler, A Gupta, H Funke, T Reich, C Hennig, A Rossberg, H-J Pietzsch, R Alberto, and B Johannsen. 2000. "EXAFS analyses of technetium(I) carbonyl complexes stability studies in solutions.” Radiochimica Acta 88:239-245.

Shuh, DK, Lukens, WW, Burns, CJ. 2003. Final Report, Research Program to Investigate the Fundamental Chemistry of Technetium, LBNL-54240, 10/2000- 9/2003.

Smellie JAT, F Karlsson, and WR Alexander. 1997. "Natural Analogue Studies: Present Status and Performance Assessment Implications.” Journal of Contaminant Hydrology 26:3-17.

Smellie JAT and F Karlsson. 1999. "The Use of Natural Analogues to Assess Radionuclide Transport.” Engineering Geology 52:193-220.

Song, YQ. 2007. “Novel NMR Techniques for Porous Media Research.” Cement and Concrete Research 37:325-328.

Steefel CI and PC Lichtner. 1998. "Multicomponent Reactive Transport in Discrete Fractures II: Infiltration of Hyperalkaline Groundwater at Maqarin, Jordan, a Natural Analogue Site.” Journal of Hydrology 209(1-4):200-224.

Taylor-Pashow, KM, CA Nash, CL Crawford, DJ McCabe, and WR Wilmarth. 2014. Laboratory Scoping Tests of Decontamination of Hanford Waste Treatment Plant Low Activity Waste OffGas Condensate Simulant, SRNL-STI-2013-719, Savannah River National Laboratory, Aiken, South Carolina. 
SRNL-STI-2013-00002

PNNL-22103

Revision 1

Um W, MM Valenta, CW Chung, J Yang, MH Engelhard, RJ Serne, KE Parker, G Wang, KJ Cantrell, and JH Westsik, Jr. 2011. Radionuclide Retention Mechanisms in Secondary WasteForm Testing: Phase II. PNNL-20753, Pacific Northwest National Laboratory, Richland, Washington.

Westsik JH Jr, RJ Serne, EM Pierce, AD Cozzi, C Chung, and DJ Swanberg. 2012. Supplemental Immobilization Cast Stone Technology Development and Waste Form Qualification Testing. PNNL-21823, Pacific Northwest National Laboratory, Richland, Washington.

Westsik JH Jr and RJ Serne. 2012. Secondary Waste Cast Stone Waste Form Qualification Testing Plan. PNNL-21656 Rev 1, Pacific Northwest National Laboratory, Richland, Washington.

Westsik, JH Jr., GF Piepel, MJ Lindberg, PG Heasler, TM Mercier, RL Russell, AD Cozzi, WE Daniel, RE Eibling, EK Hansen, MM Reigel, and DJ Swanberg. 2013. Supplemental Immobilization of Hanford Low-Activity Waste: Cast Stone Screening Tests. PNNL-22747, SRNL-STI-2013-00465, Pacific Northwest National Laboratory, Richland, Washington.

Worden, RH. 2006. "Dawsonite Cement in the Triassic Lam Formation, Shabwa Basin, Yemen: A Natural Analogue for a Potential Mineral Product of Subsurface $\mathrm{CO}_{2}$ Storage for Greenhouse Gas Reduction." Marine and Petroleum Geology 23:61-77. 
SRNL-STI-2013-00002

PNNL-22103

Revision 1

\section{Distribution:}

US Department of Energy

KD Gerdes

MA Gilbertson

DJ Koutsandreas

NP Machara

KG Picha

JE Rhoderick

SP Schneider

TA Shrader

AC Williams

US Department of Energy

Office of River Protection

JA Diediker

TW Fletcher

WF Hamel

BJ Harp

CC Harrington

LK Holton

AA Kruger

SH Pfaff

I Wheeler

Pacific Northwest National Laboratory

PR Bredt

CF Brown

RA Peterson

BM Rapko

RJ Serne

JD Vienna

DM Wellman

JH Westsik, Jr.
Savannah River National Laboratory

TB Brown

AD Cozzi

SD Fink

KM Fox

JC Griffin

CC Herman

DT Herman

EN Hoffman

CA Langton

SL Marra

DJ McCabe

DH McGuire

CA Nash

FM Pennebaker

RR Seitz

WR Wilmarth

Washington River Protection Solutions

C Burrows

WG Ramsey

RA Robbins

PL Rutland

SA Saunders

K Subramanian

DJ Swanberg

LE Thompson

M Thorson

Savannah River Remediation

KH Rosenberger

SP Simner

AV Staub

Independent Strategic Management Solutions

$\mathrm{J}$ Tseng 